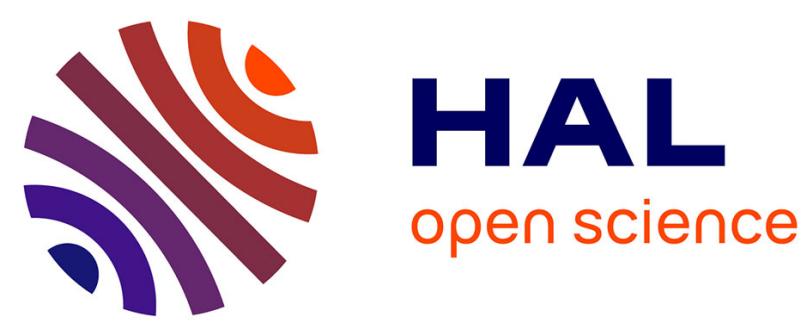

\title{
Butterfly Mesogens Based on Carbazole, Fluorene or Fluorenone: Mesomorphous, Gelling, Photophysical, and Photoconductive Properties
}

Jun-fang Hang, Hang Lin, Ke-qing Zhao, Ping Hu, Bi-qin Wang, Hirosato Monobe, Chenhui Zhu, Bertrand Donnio

\section{To cite this version:}

Jun-fang Hang, Hang Lin, Ke-qing Zhao, Ping Hu, Bi-qin Wang, et al.. Butterfly Mesogens Based on Carbazole, Fluorene or Fluorenone: Mesomorphous, Gelling, Photophysical, and Photoconductive Properties. European Journal of Organic Chemistry, 2021, 2021 (13), pp.1989-2002. 10.1002/ejoc.202100108 . hal-03407941

\section{HAL Id: hal-03407941 \\ https://hal.science/hal-03407941}

Submitted on 28 Oct 2021

HAL is a multi-disciplinary open access archive for the deposit and dissemination of scientific research documents, whether they are published or not. The documents may come from teaching and research institutions in France or abroad, or from public or private research centers.
L'archive ouverte pluridisciplinaire HAL, est destinée au dépôt et à la diffusion de documents scientifiques de niveau recherche, publiés ou non, émanant des établissements d'enseignement et de recherche français ou étrangers, des laboratoires publics ou privés. 


\title{
Butterfly Mesogens Based on Carbazole, Fluorene or Fluorenone: Mesomorphous, Gelling, Photophysical, and Photoconductive Properties
}

\author{
Jun-Fang Hang,[a] Hang Lin,[a] Ke-Qing Zhao, ${ }^{*}$ [a] Ping Hu, [a] Bi-Qin Wang,[a] Hirosato \\ Monobe, ${ }^{*}[\mathrm{~b}]$ Chenhui Zhu, [c] and Bertrand Donnio*[d]
}

Cite as Eur. J. Org. Chem. 2021, 16, 1106-1117

Publication Date: February 26, 2021

https://doi.org/10.1002/ejoc.202100108

\begin{abstract}
A generic synthetic method based on the Suzuki-Scholl reactions was successfully exploited to yield new poly(hetero)aromatic hydrocarbons containing carbazole, fluorene or fluorenone moieties. These butterfly-like mesogens exhibit columnar mesophases, form fibrous gels in various solvents, emit blue to orange light in films and solutions and show outstanding photocurrent behavior with charge carrier mobility in the $\sim 0.03 \mathrm{~cm}^{2} \mathrm{~V}^{-1} \mathrm{~s}^{-1}$ range.
\end{abstract}

\begin{abstract}
We report a straightforward and generic synthesis of several new series of annulated $\pi$ extended poly-(hetero)aromatic hydrocarbons (PAH), with carbazole, fluorene and fluorenone central building blocks by the Suzuki-Miyaura/Scholl tandem reactions. The corresponding series of ditriphenylene discogens with a carbazole or a fluorenone central core, respectively, possess hexagonal columnar mesophases with broad mesophase ranges and high clearing points, as well as demonstrate a strong aggregation tendency in organic solvents as supergelators. The laterally-substituted

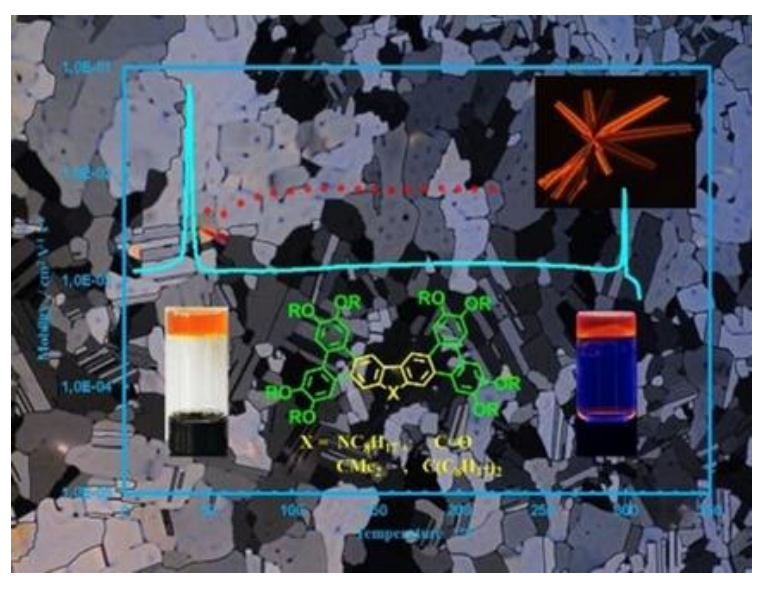
ditriphenylene mesogens based on dimethyl-fluorene core exhibit a rich polymorphism with rectangular and hexagonal columnar mesophases from low temperatures onward, whereas their dioctyl-fluorene homologues melt directly into the isotropic liquid without showing mesophases. These latter family of compounds are luminescent with very high fluorescent quantum yields, of around $70 \%$ in solution, and show outstanding photocurrent behavior with charge carrier mobility in the $10^{-2} \mathrm{~cm}^{2} \mathrm{~V}^{-1} \mathrm{~s}^{-1}$ range, as measured by photocurrent transient time-of-flight (TOF) technique. This straightforward molecular design and simple synthetic strategy proved to be both potent and resilient, and could be generally applied to the fabrication of a great variety of other heteroarene molecular systems as organic semiconductors and electroluminescent materials for potentially low-cost applications.
\end{abstract}




\section{Introduction}

Conjugated polymers with carbazole, fluorene and fluorenone building blocks are important plastic electronic materials and widely studied as active layers for various electronic devices, such as organic light-emitting diodes (OLED), $\underline{\underline{1}}$ organic photovoltaic cells (OPV) ${ }^{2}$ and organic field-effect transistors (OFET). $\underline{3}$ The corresponding low-molecular weight liquid crystalline systems and oligomers based on these three building blocks also exhibit outstanding optical/electronic properties in addition to show spontaneous self-organization behavior. They have however been much less investigated than their polymeric counterparts due essentially to some chemical/thermal/photo stability, solubility or processability issues.

Particularly promising, $\pi$-conjugated polyfused (hetero)aromatic hydrocarbons (PAH) forming discotic liquid crystals (DLCS) are considered to play a crucial role in the next generation of organic semiconductors. They can indeed exhibit one-dimensional high charge carrier (electrons or holes) mobility values due to their propensity to self-organize into long-range ordered supramolecular columns, $\underline{4}$ and their unique structural defects self-healing capability, chemical robustness and costeffective solution-processed electronic devices fabrication represent interesting and competitive assets in the field of organic semiconductors.

Carbazole-containing liquid crystals with nematic $(\mathrm{N})$ and smectic $\mathrm{A}(\mathrm{SmA})$ phases have been applied in OLED for hole transport layers ${ }^{5}$ or light-emitting layers,,-6 wile their mesophase types, transition temperatures and solubility could be modulated by the alkyl chain length grafted onto the $\mathrm{N}$-atom. However, the molecular engineering of carbazole derivatives for columnar mesophase did not initially succeed. First successful attempts combining triphenylene and carbazole units, connected through flexible spacers into dyads and heptamers were only recently reported. $\underline{-}$ Recent molecular designing strategies using carbazole as the discotic core ${ }^{-}$or directly sigma-bonded triphenylene-carbazole, $\underline{\underline{9}}$ starshaped triazine-carbazole $\frac{10}{}$ were successful in the construction of columnar mesophase materials as electronic conductors. Other ordered electronic materials such as co-dendrimers made of carbazole/mesogen mixtures $\underline{11}$ were also reported to possess mesomorphous behavior and good electronic properties.

Structurally similar to carbazole, $\pi$-conjugated fluorene rigid building block is also capable of yielding potentially interesting opto-electronic mesogenic materials. Fluorene rod-like liquid crystals were reported to exhibit $\mathrm{N}$ and SmA phases, and fabricated for polarizing OLED. $\frac{12}{}$ Further, deep-blue emissive spiro-fluorene derivatives $\underline{13}$ were tuned to displaying columnar rectangular/hexagonal mesophases. Wong studied star-shaped hexabenzocoronene-fluorene systems ${ }^{14}$ as discotic columnar electronic materials and investigated their performance in OPV and OFET devices. $\frac{15}{}$ Triphenylenefluorene dyads and triads, showing nematic and hexagonal columnar mesophases with high charge carrier mobility were also recently reported. $\underline{16}$

Similarly, fluorenone is another attractive building block, as its planar structure and functional polar ketone group are beneficial for promoting closer $\pi-\pi$ stacking and monitoring optical/electronic properties modulation. Some mesogenic fluorenones with SmA phase exhibited hole mobility of $10^{-2}$ $\mathrm{cm}^{2} \mathrm{~V}^{-1} \mathrm{~s}^{-1}, \underline{17}$ and power conversion efficiency of $0.8 \%$ in solar cells. $\underline{18}$ Until now, not many examples of $\pi$-extended mesogenic electronic materials inserting carbazole, fluorene and fluorenone building blocks, such as in triindoles, $\underline{\underline{19}}$ truxenes $\underline{\underline{20}}$ and truxenones, $\underline{\underline{21}}$ have been reported, despite their great potential for the further development of organic electronic materials-based devices.

In this work, we report the general synthesis of three novel families of butterfly-like molecules based on ditriphenylenes fused with carbazole, fluorene and fluorenone central cores, respectively (Figure 
1). Starting from the commercially available carbazole, fluorene and fluorenone building blocks, the three series of annulated ditriphenylene compounds were obtained by the combination of two emblematic chemical reactions, namely the $\mathrm{Pd}\left(\mathrm{PPh}_{3}\right)_{4}$-catalyzed Suzuki-Miyaura cross-coupling $\underline{22}$ and the $\mathrm{FeCl}_{3}$-catalyzed Scholl $\underline{23}$ intramolecular oxidative cyclo-dehydrogenation. Their liquid crystalline and gel self-assemblies were investigated, and their optical and charge carrier properties were evaluated.
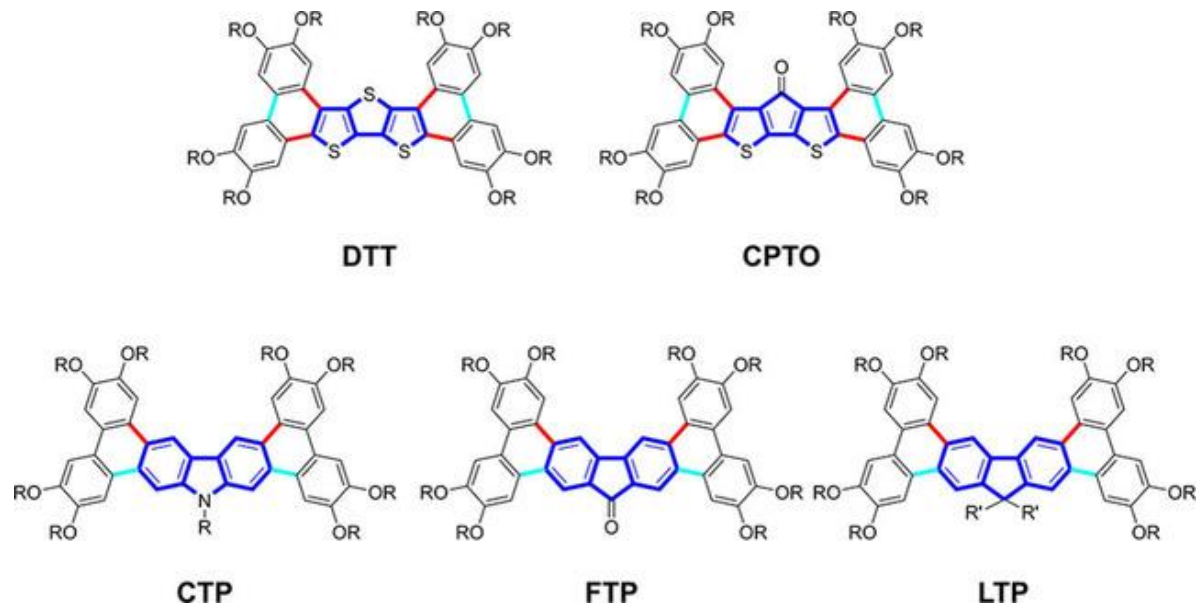

Figure 1. Examples of some previously and currently reported butterfly-like mesomorphous heteroarenes containing tristhiophene (DTT), $\underline{24}$ cyclopentan-dithiophen-4-one (CPTO), $\underline{25}$ carbazole (CTP), fluorenone (FTP) and fluorene (LTP) building blocks, respectively.

\section{Results and Discussion}

Rational molecular design and synthesis Planar, polycyclic aromatic hydrocarbons (PAH) with multiple peripheral alkyl chains are typical discotic liquid crystals (DLCS) and can be considered as potential organic one-dimensional semiconductors due to their high propensity to self-organize into supramolecular columns and to favor the unidirectional mobility of the charges (electrons or holes). Flexibility and rigidity of the molecular conformation as well as the number and length of the irradiating aliphatic chains have been used to modulate supramolecular packing and liquid crystalline properties. Despite active research in the field of molecular electronic, the diversity of charge carrying DLCs remains however quite limited, though it is increasing steadily with the progress and implementation of original synthetic strategies and with the increasing availability of some key functional building blocks. Elementary blocks like dibenzothiophene, dithienothiophene, carbazole, furan, fluorene, spirofluorene, and fluorenone derivatives, to cite but a few of them, represent ideal functional cores in organic electronic, and can be synthetically or are commercially available now. They thus become ubiquitous for the design and synthesis of novel, low symmetry DLCs for potential uses in various organic electronic-based applications. ${ }^{4}$ We have recently developed an efficient strategy based on a tandem of model reactions, namely the $\mathrm{Pd}\left(\mathrm{PPh}_{3}\right)_{4}$-catalyzed Suzuki-Miyaura cross-coupling and the $\mathrm{FeCl}_{3}$-catalyzed Scholl oxidative annulation reactions, to construct novel butterfly-like shape molecules showing mesomorphous and promising hole and electron charge carriers behaviors (DTT, CPTO, Figure 1). $\cdot \underline{-2}-\underline{26}$

The key of this generic methodology for the synthesis of these new ditriphenylenes (CTP, LTP, FTP) lies on the availability of specific carbazole-, fluorene- and fluorenone-containing polybromide precursors and/or corresponding boronic esters (or to a lesser extend their hydroxyl homologs), $\underline{\underline{27}}$ not always 

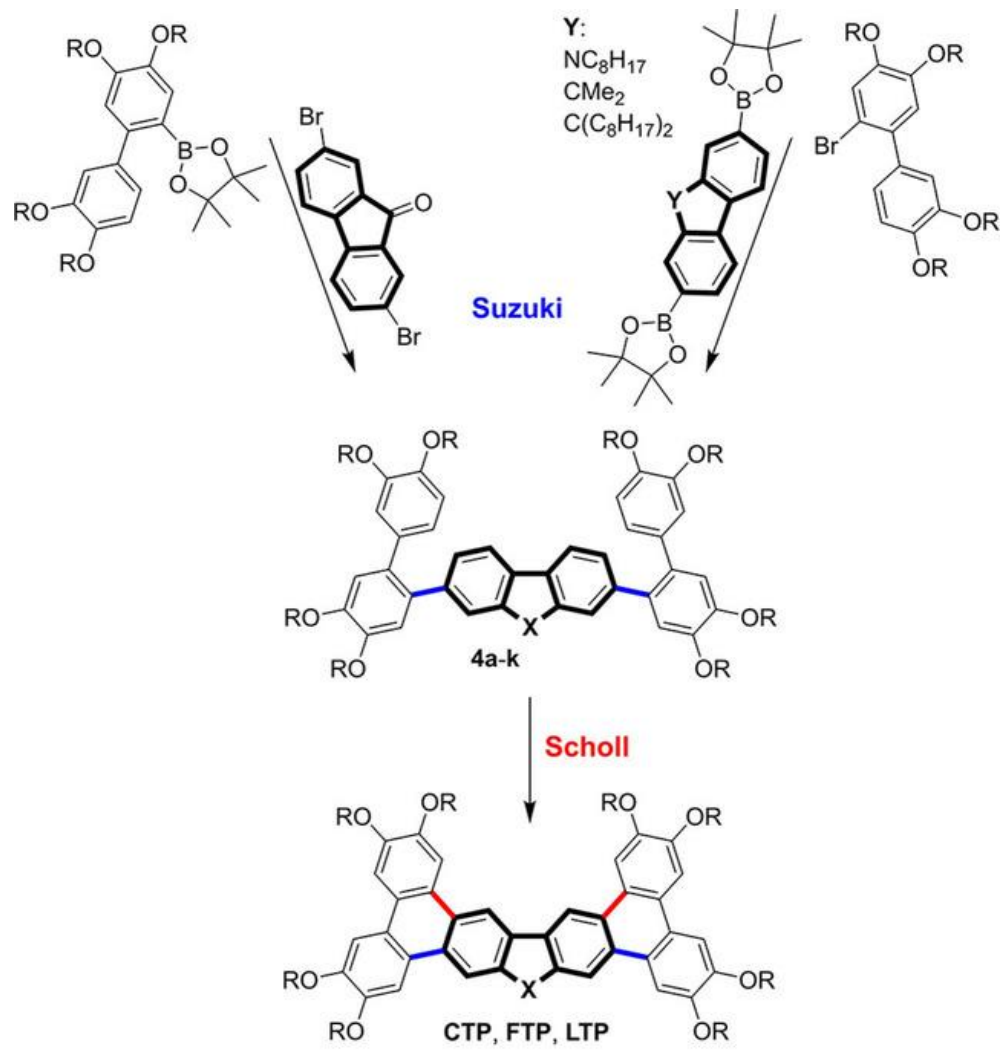

\begin{tabular}{|c|c|c|c|c|c|c|c|c|}
\hline$x$ & \multicolumn{2}{|c|}{$\mathrm{NC}_{8} \mathrm{H}_{17}$} & \multicolumn{2}{|c|}{$\mathrm{CO}$} & \multicolumn{2}{|c|}{$\mathrm{CMe}_{2}$} & \multicolumn{2}{|c|}{$\mathrm{C}\left(\mathrm{C}_{8} \mathrm{H}_{17}\right)_{2}$} \\
\hline 5 & - & - & - & - & $4 e$ & LTP5 & $4 i$ & LTP58 \\
\hline 8 & - & - & - & - & $4 f$ & LTP8 & $4 j$ & LTP88 \\
\hline 10 & - & & $4 c$ & FTP10 & $4 \mathrm{~g}$ & LTP10 & $4 k$ & LTP108 \\
\hline 12 & $4 a$ & СТP12 & $4 d$ & FTP12 & $4 \mathrm{~h}$ & LTP12 & - & - \\
\hline 14 & $4 b$ & CTP14 & - & - & - & - & - & - \\
\hline
\end{tabular}

Scheme 1. Synthesis and chart of CTP, FTP and LTP butterflies and precursors. Reaction conditions: Suzuki coupling, $\mathrm{Pd}\left(\mathrm{PPh}_{3}\right)_{4}, \mathrm{~K}_{2} \mathrm{CO}_{3}, \mathrm{H}_{2} \mathrm{O} / \mathrm{THF}, 65^{\circ} \mathrm{C}$; Scholl annulation, $\mathrm{FeCl}_{3}, \mathrm{MeNO}_{2} / \mathrm{CH}_{2} \mathrm{Cl}_{2} . \mathrm{R}=\mathrm{C}_{n} \mathrm{H}_{2 n+1}$, with $n=5,8,10,12$ and 14 . Chemical procedures are detailed in the supporting information.

easily accessible, as reported in Scheme $\underline{1}$. Numerous strategies have been developed for the synthesis of carbazole-based materials and most of them involve bromide derivatives as starting materials. Just to cite but a few, the direct bromination of carbazole results in 1,3,6,8-tetrabromocarbazole, which has been used for the synthesis of some functional 1,3,6,8-tetraarylcarbazole materials. $\underline{8}, \underline{28}$ The synthesis of some larger fused $\pi$-systems was performed from 2,3,6,7-tetrabromocarbazole and 1,2,3,6,7,8-hexabromocarbazole, however prior required sequential brominations of 2,7dibromocarbazole (and/or of its $\mathrm{N}$-alkyl derivatives) by precisely controlling bromine concentration, reaction time and temperature. $\underline{29}$ Here, the two novel large $\mathrm{N}$-heteroarene discogenic diphenanthro[9,10- $\left.b: 9^{\prime}, 10^{\prime}-h\right]$ carbazoles, CTP12/14, were directly synthesized by Suzuki-Miyaura cross-coupling between the commercial $N$-octyl carbazole-2,7-diboronic ester and the alkylatedsubstituted 2-bromo-1,1'-biphenyl (Scheme S1), subsequently followed by the $\mathrm{FeCl}_{3}$-catalyzed Scholl annulation. The same strategy was followed for the alkyl-substituted fluorene-fused ditriphenylenes (LTP5/8/10/12/58/88/108), obtained from the available 9,9-dialkylfluorene-2,7-diboronic esters. The fluorenone-fused ditriphenylenes, FTP10/12, were obtained by the inverted alternative, starting with the conversion of the appropriate lipophilic 2-bromo-1,1'-biphenyl into its 1,1'-biphenyl-2-boronic ester first, followed by the subsequent reaction with the commercially available 2,7-dibromo-9- 
fluorenone. The oxidative Scholl annulation led to the desired pure compounds, and proceeded in rather satisfying yields (ca. ranging between 47 to $94 \%$ ), whereas for the Suzuki coupling reactions, yields were greater than $60-70 \%$ up to quantitative, except for two of them ( $4 \mathrm{~d} / \mathrm{e}$, Supplementary Information), whose yields were below $50 \%$, due to purification processes.

All the synthesized ditriphenylene discogens CTP12/14, FTP10/12, LTP5/8/10/12 and LTP58/88/108 and precursors $(\mathbf{4} \mathbf{a}-\mathbf{k})$ were fully characterized by ${ }^{1} \mathrm{H}$ NMR and micro elemental analysis, with additional ${ }^{13} \mathrm{C}$ NMR and HRMS for the final target compounds (Figures S1-S43 and S45-S55 in Supporting Information). Among the synthesized discogens, the CTP and FTP compounds strongly aggregate in solution, due to their low solubility in organic solvents. Their purification was performed by silica gel column chromatography in hot toluene.

Thermal behavior, structural properties, and supramolecular organizations The chemical stability of these molecules was verified by thermal gravimetrical analysis (TGA). All the ditriphenylenes were found to show rather high thermal stability, irrespective of the heteoarenic core, chains' length or topology (linear or bifurcated). The decomposition temperatures at $1 \%$-, $2 \%$ - and $5 \%$-weight-loss were systematically higher than $340{ }^{\circ} \mathrm{C}, 361^{\circ} \mathrm{C}$ and $377^{\circ} \mathrm{C}$, respectively (Table S4, Figure S63). Their clearing temperatures were far lower than their thermal decomposition temperatures, so all were candidates for further investigations.

The liquid crystalline properties of the targeted ditriphenylene discogens were studied by polarized optical microscopy (POM, Figure $\underline{2}$ and Figure S62) and differential scanning calorimetry (DSC, Figure $\underline{3}$ and Figure S64, Table S5). As first revealed by POM, the carbazole-, fluorenone- and some of the fluorene-based butterflies are mesomorphous and, as anticipated from other structurally related systems, $\underline{\underline{4}-\underline{26}}$ they self-organize into columnar mesophases. POM photographs (Figure $\underline{2}$ and Figure S62) of CTP12/14 and FTP10/12 display the characteristic fan-shaped textures of hexagonal columnar mesophases. When the samples were slowly cooled from the isotropic liquid to the anisotropic state, the compounds held between two glass plates showed birefringent textures with strong tendency for face-on orientation. This typical optical texture originates likely from the strong anisotropy of the supramolecular columns resulting from efficient $\pi-\pi$ face-to-face stacking, while the straight defectlines implied long-range stacking ordering within the columns. The presence of large homeotropic zones in some cases conveys to uniaxial columns orthogonally arranged in hexagonal arrays. An important increase of the mesophase stability by ca. $100^{\circ} \mathrm{C}$ is observed on changing from the carbazole-containing compounds (CTP) to the fluorenone (FTP) derivatives (Figure $\underline{3}$ ). The carbazole compounds show clearing points of ca. $200^{\circ} \mathrm{C}$ and columnar mesophase ranges are about $100{ }^{\circ} \mathrm{C}$ large. The fluorenone derivatives display higher clearing temperatures, around ca. $280-300^{\circ} \mathrm{C}$, and mesophases with twice wider ranges, of ca. $210-240^{\circ} \mathrm{C}$, respectively. These observations seem to be in agreement with their respective molecular structures. On the one hand, the presence of the polar ketone group in the $\pi$-conjugating core of the fluorenones favors strong antiparallel dipole-dipole interactions in the columnar stacks, whereas the octyl chain irradiating from the carbazole unit, on the other hand, also promoting this antiparallel arrangement, must somehow interfere with the stacking. For the dimethyl fluorene-based derivatives, LTP5/8/10/12, POM analysis reveals the absence of mesomorphic behavior for LTP5, exhibiting highly colored mosaic texture and straight-line defects, typical of a crystalline phase (Figure S62). However, the other LTP8/10/12 compounds with longer linear chains, all exhibit broken fan-shaped, small domains and homeotropic zones in the high temperature mesophase, strongly pointing to the occurrence of a Colnex mesophase as for the carbazole and fluorenone derivatives. On further cooling, the textures change to mosaic-like texture for LTP8 and needle-like textures for LTP10 and LTP12, indicating the transition to another mesophase of lower symmetry. However, by this technique only, the nature of the mesophases could not be 
unequivocally confirmed. The optical textures persist down to low temperatures, particularly for LTP8, well below the phase' transition, but signs of crystallization could eventually be observed. The maximum mesophase extension is observed for the decyl homolog, $142^{\circ} \mathrm{C}$ for LTP10, concomitantly with the decrease of both clearing and melting temperatures (Figure $\underline{3}$ ). The presence of the two methylene groups lying perpendicularly to the molecular plane must certainly optimize the efficiency of the molecular stacking by locking the antiparallel stacking of the molecules, thus promoting the formation of highly cohesive supramolecular columns organized in mesophases. The substitution of the methylene groups by the two long octyl chains in the LTP58/88/108 congeners, although contributing largely to the depression of the melting temperatures by $\mathrm{ca} .100^{\circ} \mathrm{C}$, appears however detrimental to the emergence of mesomorphism (Figure S62). The bulky protruding chains lying perpendicularly to the molecular plane in this case likely thwart the efficiency of the molecular stacking, and impact on the phase stability. Of interest, the behavior of these annulated $\pi$-extended fluorene molecules is very different from that of recently reported triads made of a fluorene-bridged sigma-bonded with two triphenylene, displaying nematic/columnar mesophases, resulting from the more flexible molecular conformation. $\underline{16}$

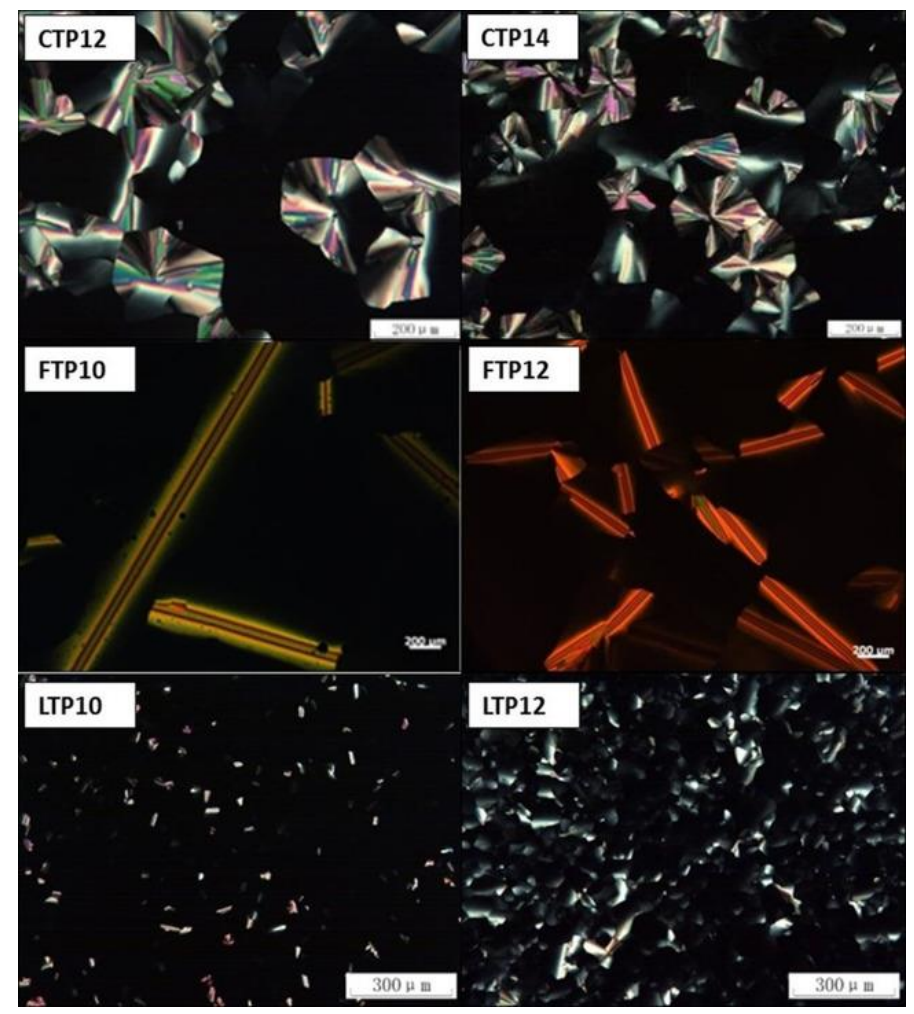

Figure 2. Representative POM images textures of CTP12 $\left(120^{\circ} \mathrm{C}\right), \mathbf{C T P} 14\left(145^{\circ} \mathrm{C}\right), \mathrm{FTP} 10\left(260^{\circ} \mathrm{C}\right), \mathbf{F T P} 12\left(220^{\circ} \mathrm{C}\right)$, LTP10 $\left(185^{\circ} \mathrm{C}\right)$ and $\operatorname{LTP} 12\left(180^{\circ} \mathrm{C}\right)$, obtained on slowly cooling from the isotropic liquid. Additional POM images can be found in the Supplementary file (Figure S63).

The transition temperatures were duly confirmed by DSC (Figure S64, Table S5). DSC thermograms also revealed the polymorphic nature of CTP and LTP compounds. In general, the thermal behavior of all the compounds were found to be fully reversible and reproducible after several heating/cooling cycles, confirming their excellent thermal stability. Notice that another transition was also detected by DSC on cooling only for the LTP10 homolog, suggesting the induction of a monotropic phase, see below (Figure $\underline{3}$ ). 


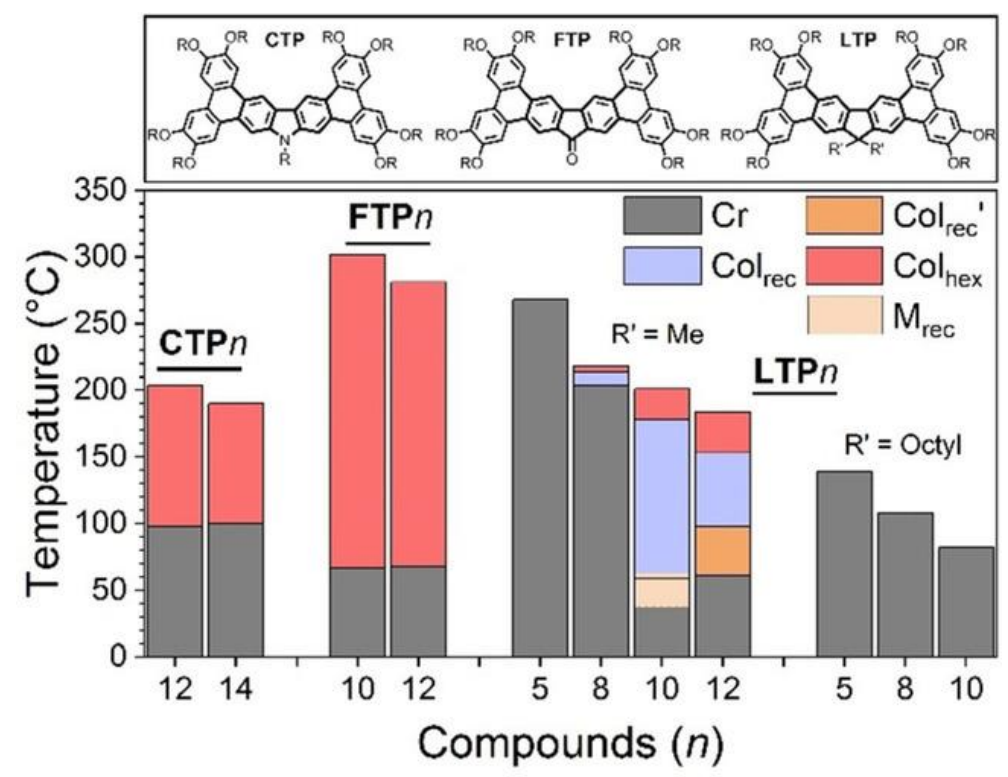

Figure 3. Phase diagram of the fused ditriphenylenes CTP12/14, FTP10/12, LTP5/8/10/12 and LTP58/88/108 $\left(\mathrm{R}=\mathrm{C}_{n} \mathrm{H}_{2 n+1}\right)$. Second heating run shown. $\mathrm{Cr}$ : crystalline phase; Colnex: hexagonal columnar phase; Colrec and Colrec': rectangular columnar phases; Mrec: monotropic phase with a rectangular 2D symmetry (see S/WAXS analysis for mesophase identification).

The nature of the mesophases and supramolecular organizations of these various butterfly-shaped ditriphenylenes were studied by small- and wide-angle X-ray scattering (S/WAXS, Figure S65, Table S6) and the main geometrical data are summarized in Table $\underline{1}$. The S/WAXS patterns indistinctly possess the characteristic features of liquid-crystalline phases with sharp, small-angle reflections emerging from the nanosegregated structure formed by the antagonistic aromatic and aliphatic segments, along with the scattering signals in the wide-angle region, $h_{c h}$ and $h_{\pi}$, emerging respectively from liquid-like lateral distances between molten chains $\left(h_{\mathrm{ch}} \sim 4.50-4.80 \AA\right)$ ) and from the stacking between the juxtaposed mesogenic cores $\left(h_{\pi} \sim 3.40-3.90 \AA\right)$; let us remark that this latter signal is present for almost all compounds, though rather weak for some of them, and systematically decreases until its complete collapsing at or near the clearing temperature (Figure S65).

The assignment of the Col hex mesophase made by POM for CTP12/14, FTP10/12 and LTP10/12 was unambiguously confirmed by S/WAXS. The presence of one very sharp and intense first-order reflection (10), along one or two weaker, additional higher-order reflections, indexed as (11) and (20), respectively, according to the sequence of spacing ratios $1: \sqrt{ } 3: \sqrt{ } 4$ (Figure 4 ), confirms the long-range ordering of a two-dimensional hexagonal lattice. The high-temperature mesophase of LTP8 could only be identified by POM (i.e. Col $\left.\right|_{\text {hex, }}$ Figure S62) due to its limited temperature range preventing conclusive S/WAXS acquisition. Whereas only one mesophase is formed for both CTP and FTP compounds, additional mesophases below the Colhex mesophases were detected for the mesomorphous LTP homologs. The S/WAXS patterns recorded at these temperatures exhibit a multitude of sharp peaks in the small-angle range (>12, Figure S65 for LTP8/10/12), characterizing the formation of mesophases of lower symmetry. In the wide-angle range, the same features as for the $\mathrm{Col}_{\text {hex }}$ phases discussed above were found, except for the considerable enhancement of the core-core stacking peak's intensity in most cases $\left(h_{\pi} \sim 3.53-3.64 \AA\right.$, correlation length $\zeta \sim 100$ for LTP8 and $\zeta \sim 115-$ 130 for LTP12), evidencing higher overlapping of the extended fluorene cores and the extension of the columnar stacking. The solutions provided by the peaks' indexation (Table S6) convey to 2D rectangular lattices and to the assignment of rectangular columnar mesophases made of two supramolecular columns per lattice. The numerous sharp, small-angle diffraction peaks systematically observed for 
these compounds along with the peaks' intensity distribution, reveal the long-range two-dimensional correlated lattices and well defined interfaces, characterized by the efficient segregation between the non-miscible parts, i.e. the supramolecular columns, resulting from the regular stacking of the mesogenic cores localized at the nodes of the lattice, and the molten aliphatic infinite continuum between the columns. Detailed peaks' analysis (Table 1 and Table S6) further indicated two different planar symmetries for the $\mathrm{Col}_{\text {rec }}$ mesophases i. e. $c 2 \mathrm{~mm}$ and $p 2 \mathrm{gg}$, corresponding respectively to the specific orientations of the elliptical columnar cross-sections within the rectangular lattices, the long elliptical axis lying along the $a$-axis for the centrosymmetric $c 2 \mathrm{~mm}$ lattice, or alternating its orientation with respect to the same $a$-axis (Figure $\underline{4}$ ) to form a ribbon-like arrangement for the $p 2 g g$ one. ${ }^{30}$

\begin{tabular}{|c|c|c|c|c|c|c|c|c|c|c|c|c|c|}
\hline \multirow[t]{2}{*}{ Cpds } & \multirow[t]{2}{*}{$T^{\left.[]^{2}\right]}$} & \multirow{2}{*}{$\begin{array}{l}V_{m a d}^{|b|} \\
\rho\end{array}$} & \multirow{2}{*}{$\begin{array}{l}\text { Phase } \\
\text { Plane group }\end{array}$} & \multicolumn{4}{|c|}{ Mesophase parameters $^{[d]}$} & \multirow[t]{2}{*}{$A_{\text {mol }}^{[\text {[e] }}$} & \multirow{2}{*}{$\begin{array}{l}h_{\text {mol }}{ }^{m} \\
\psi^{|g| l \mid}\end{array}$} & \multirow{2}{*}{$\begin{array}{l}h_{c}^{D N} \\
h_{s}^{11}\end{array}$} & \multirow{2}{*}{ 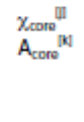 } & \multirow{2}{*}{ 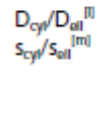 } & \multirow{2}{*}{$\begin{array}{l}q_{g y}{ }^{\operatorname{In} i} \\
/ q_{\text {ell }}\end{array}$} \\
\hline & & & & $\begin{array}{l}\mathrm{a} \\
\mathrm{b}\end{array}$ & $\gamma$ & A & $\mathrm{Z}$ & & & & & & \\
\hline \multirow[t]{6}{*}{ СТP12 } & 180 & 3824 & $\mathrm{Col}_{\text {ner }}$ & 32.24 & 120 & 900.1 & 1 & 900.1 & 4.25 & 4.65 & 0.179 & 14.32 & 1.12 \\
\hline & & 0.89 & $p 6 \mathrm{~mm}$ & 32.24 & & & & & $\approx 25$ & 3.79 & 161.1 & 21.25 & \\
\hline & 140 & 3730 & $\mathrm{Col}_{\text {her }}$ & 32.77 & 120 & 930.0 & 1 & 930.1 & 4.01 & 4.62 & 0.180 & 14.6 & 1.13 \\
\hline & & 0.91 & $p 6 \mathrm{~mm}$ & 32.77 & & & & & $\approx 20$ & 3.73 & 167.4 & 20.44 & \\
\hline & 110 & 3658 & $\mathrm{Col}_{\text {near }}$ & 33.02 & 120 & 944.4 & 1 & 944.4 & 3.87 & 4.57 & 0.182 & 14.79 & 1.13 \\
\hline & & 0.93 & $p 6 \mathrm{~mm}$ & 33.02 & & & & & $\approx 20$ & 3.68 & 171.9 & 19.98 & \\
\hline \multirow[t]{6}{*}{ СТP14 } & 180 & 4307 & $\mathrm{Col}_{\text {her }}$ & 33.94 & 120 & 997.7 & 1 & 997.7 & 4.32 & 4.68 & 0.158 & 14.17 & 1.11 \\
\hline & & 0.88 & $p 6 \mathrm{~mm}$ & 33.94 & & & & & $\approx 30$ & 3.81 & 157.6 & 21.36 & \\
\hline & 160 & 4254 & $\mathrm{Col}_{\text {ner }}$ & 34.77 & 120 & 1046.9 & 1 & 1046.9 & 4.06 & 4.60 & 0.159 & 14.56 & 1.14 \\
\hline & & 0.89 & $p 6 \mathrm{~mm}$ & 34.77 & & & & & $\approx 20$ & 3.80 & 166.5 & 20.65 & \\
\hline & 110 & 4119 & $\mathrm{Col}_{\text {hex }}$ & 35.09 & 120 & 1066.4 & 1 & 1066.9 & 3.86 & 4.58 & 0.161 & 14.78 & 1.14 \\
\hline & & 0.92 & $p 6 \mathrm{~mm}$ & 35.09 & & & & & $\approx 20$ & 3.68 & 171.8 & 19.93 & \\
\hline \multirow{4}{*}{ FTP10 } & 250 & 3258 & $\mathrm{Col}_{\text {her }}$ & 28.54 & 120 & 705.6 & 1 & 705.6 & 4.62 & 4.64 & 0.223 & 14.15 & 0.97 \\
\hline & & 0.88 & $p 6 \mathrm{~mm}$ & 28.54 & & & & & $\approx 40$ & 3.50 & 157.3 & 25.67 & \\
\hline & 150 & 3068 & $\mathrm{Col}_{\text {her }}$ & 29.79 & 120 & 768.6 & 1 & 768.6 & 3.99 & 4.55 & 0.228 & 14.93 & 0.99 \\
\hline & & 0.94 & $p 6 \mathrm{~mm}$ & 29.79 & & & & & $\approx 30$ & 3.43 & 175.2 & 23.41 & \\
\hline \multirow[t]{4}{*}{ FTP12 } & 250 & 3764 & $\mathrm{Col}_{\text {ner }}$ & 30.44 & 120 & 802.3 & 1 & 802.3 & 4.70 & 4.62 & 0.193 & 14.04 & 0.96 \\
\hline & & 0.86 & $p 6 \mathrm{~mm}$ & 30.44 & & & & & $\approx 40$ & 3.53 & 154.9 & 25.87 & \\
\hline & 150 & 3542 & $\mathrm{Col}_{\text {ner }}$ & 31.81 & 120 & 876.4 & 1 & 876.4 & 4.04 & 4.45 & 0.198 & 14.86 & 0.99 \\
\hline & & 0.92 & $p 6 \mathrm{~mm}$ & 31.81 & & & & & $\approx 30$ & 3.43 & 173.5 & 23.59 & \\
\hline \multirow[t]{2}{*}{ LTP8 } & 210 & 2743 & $\mathrm{Col}_{\mathrm{rax}}$ & 59.42 & 90 & 1558.6 & 2 & 779.3 & 3.52 & 4.65 & 0.259 & 22.67 & 1.00 \\
\hline & & 0.92 & $p 2 g g$ & 26.23 & & & & & $\approx 0$ & 3.64 & 201.8 & 24.16 & \\
\hline \multirow[t]{6}{*}{ LTP10 } & 60 & 2945 & $M_{r o x}$ & 56.25 & 90 & 1726.9 & 2 & 863.4 & 3.41 & 4.64 & 0.227 & 22.34 & 1.05 \\
\hline & & 0.98 & - & 30.70 & & & & & $\approx 0$ & 3.55 & 196.0 & 23.07 & \\
\hline & 130 & 3081 & $\mathrm{Col}_{8 x x}$ & 57.06 & 90 & 1701.5 & 2 & 850.8 & 3.62 & 4.70 & 0.223 & 21.98 & 1.05 \\
\hline & & 0.94 & $p 2 g g$ & 29.92 & & & & & $\approx 0$ & 3.59 & 189.7 & 24.10 & \\
\hline & 200 & 3217 & $\mathrm{Col}_{\text {her }}$ & 31.94 & 120 & 883.4 & 1 & 883.4 & 3.64 & 4.86 & 0.220 & 15.73 & 1.07 \\
\hline & & 0.90 & $p 6 \mathrm{~mm}$ & 31.94 & & & & & $\approx 0$ & 3.78 & 194.4 & 22.49 & \\
\hline \multirow[t]{6}{*}{ LTP12 } & 70 & 3411 & $\mathrm{Col}_{\max }$ & 61.58 & 90 & 2076.5 & 2 & 1038.2 & 3.29 & 4.65 & 0.197 & 22.82 & 1.03 \\
\hline & & 0.96 & $p 2 g g$ & 33.72 & & & & & $\approx 0$ & 3.53 & 204.5 & 22.70 & \\
\hline & 120 & 3524 & $\mathrm{Col}_{\max }$ & 66.6 & 90 & 2107.9 & 2 & 1053.9 & 3.34 & 4.60 & 0.194 & 22.82 & 1.01 \\
\hline & & 0.93 & $\mathrm{c} 2 \mathrm{~mm}$ & 31.65 & & & & & $\approx 0$ & 3.57 & 204.5 & 23.10 & \\
\hline & 180 & 3661 & $\mathrm{Col}_{\text {ner }}$ & 33.62 & 120 & 979.2 & 1 & 978.9 & 3.74 & 4.60 & 0.191 & 15.43 & 1.05 \\
\hline & & 0.89 & $p 6 \mathrm{~mm}$ & 33.62 & & & & & $\approx 0$ & 3.80 & 186.9 & 22.66 & \\
\hline \multicolumn{14}{|c|}{ 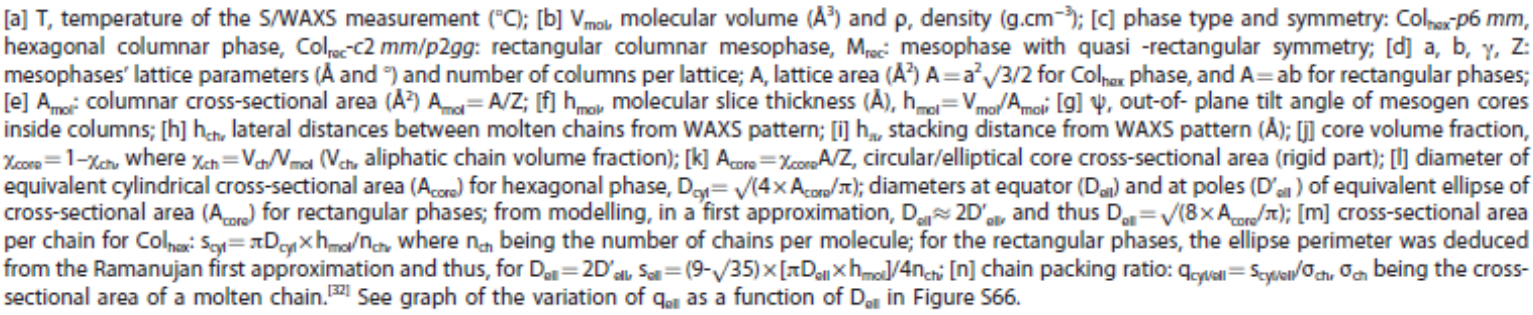 } \\
\hline
\end{tabular}

As shown by DFT calculations (Figure S57), and similarly to other structurally related compounds, $\underline{24} \underline{26}$ all these new butterfly-like molecules are planar irrespective of the nature of the central core, suggesting an easy stacking along the columnar axis. Furthermore, these calculations also reveal that their rigid aromatic core adopt an elliptical shape, with a core aspect ratio of almost 2 (i. e. as roughly estimated by the quotient $D_{\text {ell }} / D^{\prime}$ ell, diameter at equator/diameter at the poles, Table 1 ). The emergence of the hexagonal symmetry implies that the columns must exhibit a time-averaged circular cross-section which allows a homogeneous distribution of the aliphatic chains in the periphery. And indeed, the shape of the core/chain interface of the columns can take the shape of a cylinder by the 
continuous orientational change of the pseudo-elliptical mesogens along the stacking direction, with, if necessary, some tilt of the cores with respect to the lattice plane. $\frac{31}{}$

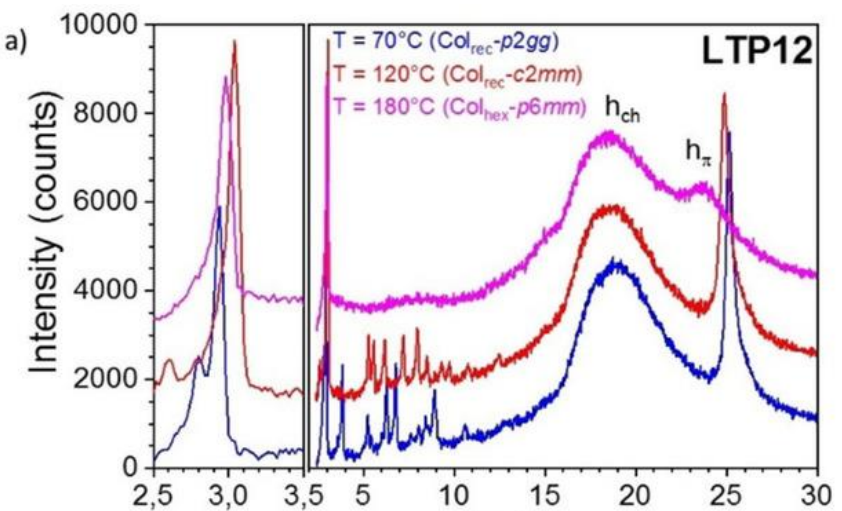

b)

$2 \theta\left({ }^{\circ}\right)$
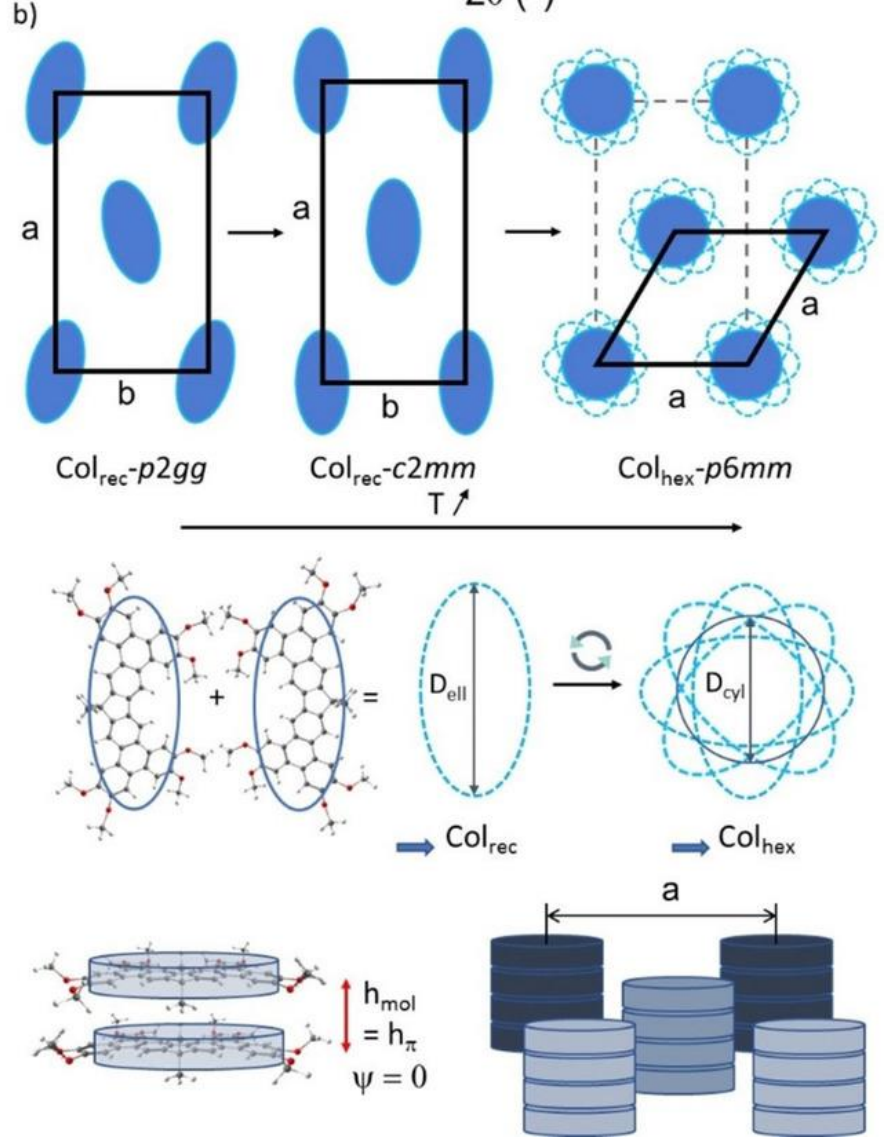

Figure 4. a) Small- and wide-angle X-ray scattering (S/WAXS) patterns of the three mesophases of LTP12 compound (chosen as a representative example) recorded on cooling at various temperatures. b) Evolution of the lattices' symmetry of the various mesophases of LTP12 as a function of temperature. Supramolecular organization in the $\mathrm{Col}_{\text {rec }}$ and Colhex phases: the elongated shape of the aromatic core roughly approximates an ellipse of aspect ratio close to 2 with an interface area per peripheral chain sell; the ellipses adopt alternated orientations with respect to a-axis $(p 2 g g)$ or are collinear to a-axis $(c 2 \mathrm{~mm})$; the random orientational changes of the stacked cores, distribute the space-demanding radiating alkyl chains over the whole stack periphery and design average cylindrical columns of reduced statistical interface area scyl; elliptical and cylindrical columns arranging in rectangular and hexagonal lattices, respectively of parameter $a$ and with molecular slice thickness $\mathrm{h}_{\text {mol }}$ compared to $\pi$-stacking distance, $\mathrm{h}_{\pi}$.

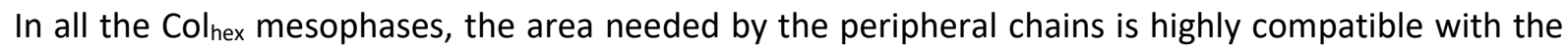
interface area offered by the stacked mesogens, since the ratio $\mathrm{q}_{\mathrm{cyl}}(\mathrm{Table} \underline{1})$ does not deviate much 
from unity ( $<10 \%$ for CTP and FTP compounds)..$\underline{32}$ The chains are therefore stretched and densely packed, allowing for facile orientational changes between neighboring molecules within and, obviously, between columns, resulting in the homogeneous distribution of the aliphatic chains at the periphery of the columns. The values of the molecular slices' thicknesses, $h_{\text {mol }}$, deduced from the ratio between the molecular volume and the columnar area, are almost similar to those of $h_{\pi}\left(h_{\text {mol }}\right.$ being slightly greater than $h_{\pi}$, Table 1) for CTP and FTP derivatives or identical to the stacking distance $\left(h_{\text {mol }} \approx h_{\pi}, \psi \approx 0\right)$ for the LTP compounds, equivalent to a non-tilted stacking of the cores along the columnar axis for the latter. In order to manage the even distribution of the central protruding chain in the CTP compounds or the carbonyl fragment in the FTP ones, the molecules must therefore stack into columns with some small tilts ( $\psi \approx 20-30$ for CTP and 30-40 for FTP, Table $\underline{1}$ ). These models (Figure 4) are in agreement with the high mesophase stability observed in these series of compounds.

The induction of the rectangular phase for the LTP systems is not in contradiction with the above, and the respective orientational changes between juxtaposed molecules must be somehow hindered by the presence of the two diverging methyl group that likely lock the molecules in a specific antiparallel arrangement. These features hamper the easy orientational changes along the piles of the $\pi$-stacked mesogens as the temperature is decreased and thus naturally lead to columns with an elliptical crosssection that arrange in a columnar phases of lower symmetry. The ratios between the molecular volume versus the area of the cell $(Z=2)$ provide values for $h_{\text {mol }}$ that do not diverge from $h_{\pi}$, consistent with orthogonal stacking $(\psi \approx 0)$. The area needed by the peripheral chains is also perfectly compatible with the interface area offered by the stacked mesogens, since the ratio qell (Table 1 ) is almost equal to unity for an elliptical columnar cross-section of aspect ratio 2 . The variation of this ratio as a function of the grand elliptical diameter $D_{\text {ell }}$, comprised between ca. 11 and $24 \mathrm{~nm}$, is comprised between.0.91.05 , highly compatible with the dimensions of the fluorene core (Table 1 , Figure S66). The transition between $\mathrm{Col}_{\text {rec }}$ and $\mathrm{Col}_{\text {hex }}$ mesophases in these LTP compounds is thus due to both orientational and translational changes of the stacked mesogenic parts along the columnar axis.

Optical physical property Carbazole, fluorene and fluorenone are ubiquitous building blocks in electronic materials used for OLEDs, OPVs, and OFETs $s^{2-4}$ and the optical properties materials containing these active units determine their future performances in optoelectronic devices.

The UV-vis absorption and photoluminescence of the different butterfly-like mesogens were measured in solution and films. For all, the $\pi$-extension increases the UV-vis absorption spectra to $400 \mathrm{~nm}$, and for FTP to almost $500 \mathrm{~nm}$, resulting from $\pi-\pi^{*}$, and intramolecular charge transfer (ICT) absorption (Table S1, Figure $\underline{5}$ and Figure S56), independently of the chains' length. All these ditriphenylene compounds also emit in both solution and in thin films. The CTP compounds dissolved in THF emit blue light in $430-550 \mathrm{~nm}$ with quantum yield (QY) of $26-27 \%$, and the emission is slightly red-shifted (ca. $10 \mathrm{~nm}$ ) in the film. All the LTP compounds show photoluminescence of blue light in the 360-520 nm range, with outstanding QY of $70 \%$, while the film fluorescence red-shifts by ca. $62 \mathrm{~nm}$. On the other hand, FTP compounds photo-luminesce with orange-yellow light between 480 and720 nm in THF, with absolute QY around $21-28 \%$, the fluorescence of the film being red-shifted by $61 \mathrm{~nm}$ compared with the emission in solution. The topology of the chain affects the film luminescence profile and $\lambda_{\mathrm{em}}$ (Table 2. Figure S56). Usually polycyclic aromatic hydrocarbons (PAHs) exhibit diminished fluorescent efficiency due to extended $\pi$-conjugation and aggregation in solution. However, the annulated ditriphenylene derivatives LTP show very high QY of $70 \%$ due to the lateral substituted dimethyl/dioctyl of fluorene core, which have potential application as fluorescent sensor and OLED materials. The blue-colored photoluminescence of CTP and LTP in solution and thin-film implied that these materials can be used in blue-light emitting OLED, as well as in electron-transport materials. $\underline{.}, \underline{\underline{6}}$ 

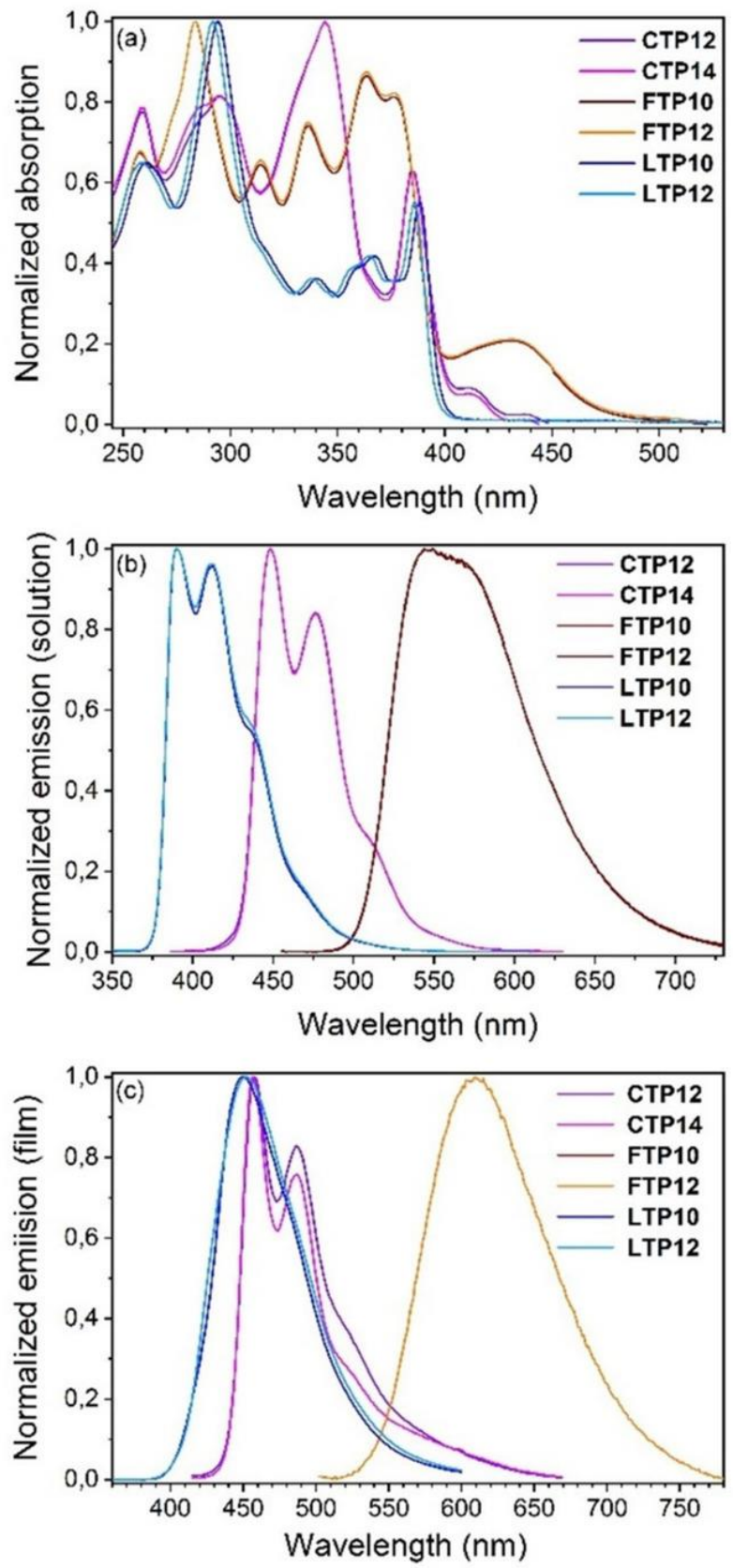

Figure 5. (a) and (b) UV-Vis absorption and fluorescent spectra, measured in THF solutions at a concentration of $1 \times 10^{-5} \mathrm{~mol} / \mathrm{L}$ with excitation of $365 \mathrm{~nm}$ for CTP, and $370 \mathrm{~nm}$ for FTP; at a concentration of $1 \times 10^{-6} \mathrm{~mol} / \mathrm{L}$ with excitation of $300 \mathrm{~nm}$ for LTP; (c) photoluminescence of thin-films, measured at $25^{\circ} \mathrm{C}$.

\begin{tabular}{|c|c|c|c|}
\hline Compounds & $\lambda_{\mathrm{am}}$ solution $[\mathrm{nm}]$ & QY $[\%]$ & $\lambda_{\mathrm{mm}}$ film $[\mathrm{nm}]$ \\
\hline CTPn & $449 / 476$ & $26.12-27.26$ & $458 / 486$ \\
\hline FTPn & 548 & $20.85-27.98$ & 609 \\
\hline LTPn & $392-393 / 413-415$ & $69.87-75.26$ & 465 \\
\hline
\end{tabular}

Molecular engineering of this semiconducting butterfly-shape coplanar ditripheylene DLCs effectively modulates the absorption and emission properties, HOMO/LUMO energy levels and energy gaps. The 
ground-state molecule geometries and the frontier molecular orbitals were calculated for these three compounds by density functional theory (DFT) at the level of B3LYP-D3/6-311 ++G (d,p) (Figure 6). The calculated HOMO/LUMO levels are $-5.31 \mathrm{eV} /-1.86 \mathrm{eV},-5.73 \mathrm{eV} /-2.75 \mathrm{eV}$ and $-5.54 \mathrm{eV} /-1.83 \mathrm{eV}$ for CTP, FTP and LTP, respectively. These theoretical results agreed well with the experimental UV-Vis absorption and luminescence spectroscopies. As expected, FTP showed downshifted HOMO/LUMO levels and narrower energy gap than CTP and LTP derivatives, resulting from the introduction of electron-withdrawing ketone unit in the central part. Furthermore, the FTP's HOMO shows the electron density localized mainly on the two tetraalkoxy-triphenylene cores whereas for the LUMO, the electrons are distributed on the central fluorenone core. The more obvious intramolecular charge transfer (ICT) absorption of FTP was demonstrated by the contrast HOMO/LUMO wavefunction distribution in theory, and the red-colored sample (organogel) and red-shifted solution/aggregation emission in experiments.

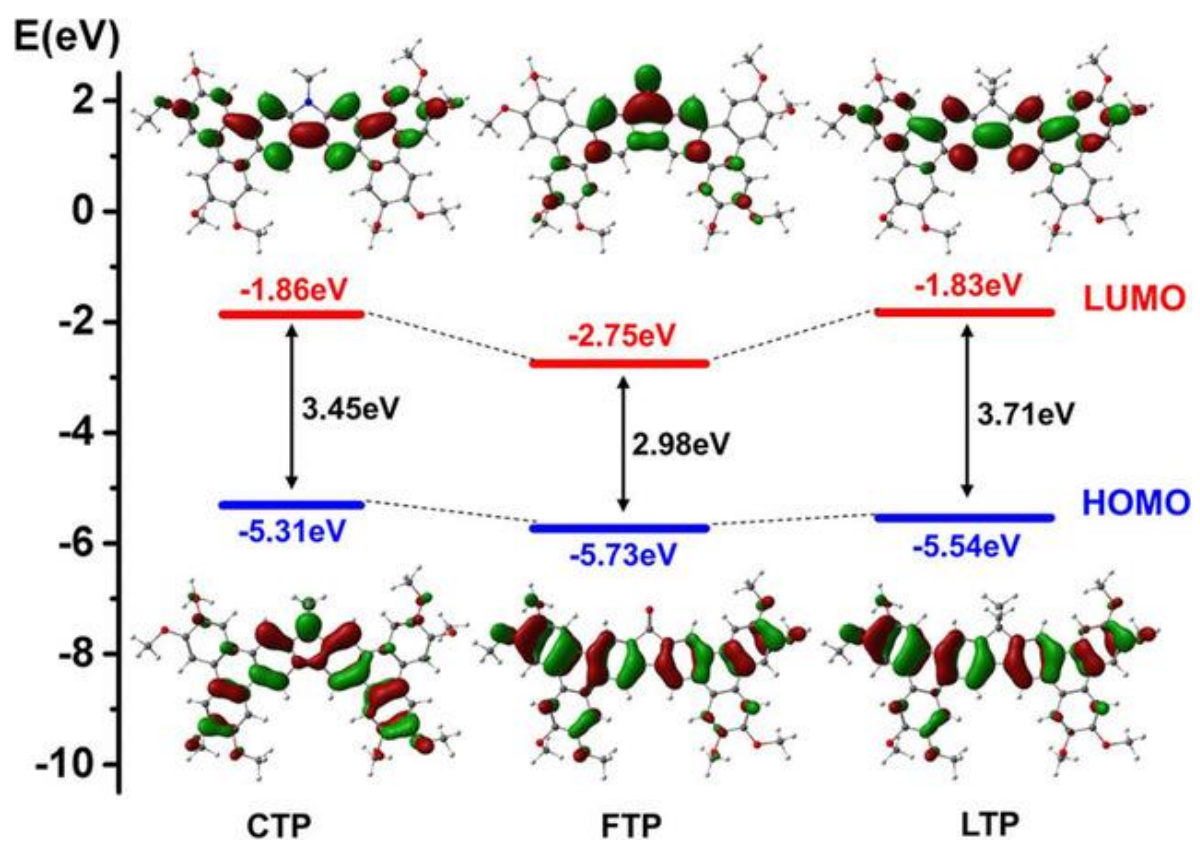

Figure 6. Calculated molecular frontier orbitals and energy levels for CTP, FTP and LTP homologs with methoxy radicals (More detailed diagrams of the HOMO-LUMO frontier orbitals can be found in Supporting Information).

Gelling properties Organic gelators possessing very strong intermolecular interactions, such as $\pi-\pi$, dipole-dipole, or hydrogen bond can lock enough solvent molecules to form organic gels. Supramolecular gelators further tend to self-assemble into intricate 3D-networks made of nano- to micro-fibers, rods, tubes or bands. $\frac{33}{}$ The present fused ditriphenylenes are extended $\pi$-conjugated aromatics with long peripheral alkyl chains, and are thus expected to also aggregate in organic solvents and thus to be good candidates as $\pi$-gelators. To test their gelling abilities, a fixed amount of the sample was dissolved in different solvents by heating until complete dissolution and then were slowly cooled down. The formation of the organogels was confirmed by the "stable to inversion of the test tube" method (Figure $\underline{7}$ and Figure S59). The gel-forming of CTP12 and LTP10 compounds are summarized in Table $\underline{3}$. We found that indeed the CTP and FTP mesogens aggregate in organic solvents and show good gelling properties. In contrast, the fluorene derivatives LTP do not aggregate in solution as evidenced from the invariance of the ${ }^{1} \mathrm{H}$ NMR spectra aromatic signals with increasing concentration (Figure S44), and as result do not form gels. The presence of the chains at the tip of the fluorene core radiating out of the molecular plane (Figure S57), may disturb efficient $\pi-\pi$ intermolecular interactions in solution and be responsible for the increase solubility in the solvents, consequently reducing its gelforming tendency. 


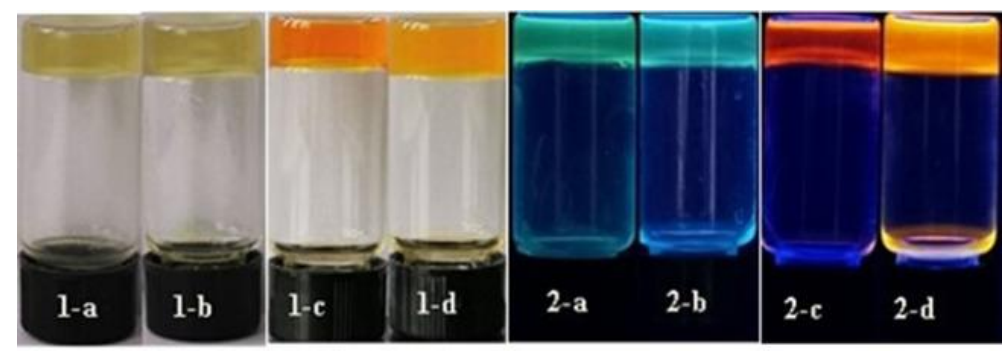

Figure 7. Gelation of CTP12 and FTP10 in various organic solvents: CTP12 in hexane (a) and cyclohexane (b); FTP10 in $\mathrm{CH}_{2} \mathrm{Cl}_{2}$ (c) and THF (d). Pictures of the gels in day light, 1-a/d, and the corresponding images under UV light $(365 \mathrm{~nm}) 2-\mathrm{a} / \mathrm{d}$.

\begin{tabular}{|c|c|c|}
\hline Solvent & CTP12 & FTP10 \\
\hline Hexane & $G(3) 0$ & $G(2) 0$ \\
\hline Cyclohexane & $G(3) 0$ & $G(2) \circ$ \\
\hline Toluene & $\mathrm{s}$ & $G(2) t$ \\
\hline $\mathrm{CH}_{2} \mathrm{Cl}_{2}$ & s & $G(2) t$ \\
\hline $\mathrm{CHCl}_{3}$ & $s$ & $G(5) t$ \\
\hline THF & s & $G(3) 0$ \\
\hline Ethanol & I & 1 \\
\hline
\end{tabular}

[a] G, S and I indicate the state of the mixture when heated, corresponding to gel, solution and insoluble, respectively. [b] The numbers in brackets correspond to the critical gelation concentration (CGC) in $\mathrm{mg} \mathrm{mL}^{-1}$. [c] o and $t$ denoted the appearance of the gel: $o$, opaque gel; $t$, transparent gel.

CTP12 can form organogel in nonpolar organic solvents such as hexane or cyclohexane, in concentration of $3.0 \mathrm{mg} \mathrm{mL}^{-1}$ (Figure 7). It also dissolves in hot polar solvents such as $\mathrm{CH}_{2} \mathrm{Cl}_{2}$ and $\mathrm{CHCl}_{3}$, but precipitates on cooling without forming gels. These gels emit blue-light under UV irradiation. FTP10 displays stronger gelling ability than CTP12, locking both nonpolar solvents (hexane, cyclohexane, toluene) and polar solvents $\left(\mathrm{CH}_{2} \mathrm{Cl}_{2}, \mathrm{CHCl}_{3}\right.$, THF) at much lower concentrations, of $2.5 \mathrm{mg} \mathrm{mL}^{-1}$ (Figure $\underline{Z}$ and Figure S59). They emit strong yellow light under UV irradiation.

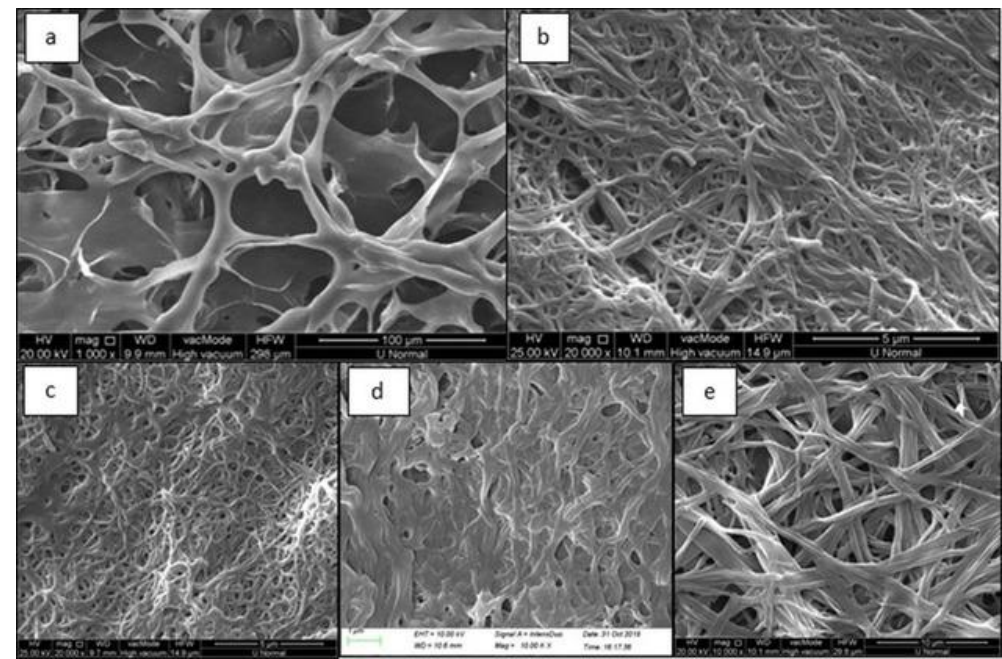

Figure 8. SEM images of xerogels of: (a) CTP12 in cyclohexane; (b) FTP-10 in hexane; (c) CTP12 in toluene/EtOH ("good"/"poor" solvent); (d) FTP10 in toluene/EtOH ("good"/"poor" solvent); (e) LTP10 in $\mathrm{CH}_{2} \mathrm{Cl}_{2} / \mathrm{EtOH}$ ("good"/"poor" solvent). Other SEM images are shown in Figures S60-S61. 
As revealed by SEM, the morphology of the xerogel formed by CTP12 in apolar solvents showed densely packed 3D networks, composed of entangled nanofibrous structures with lengths of more than several micrometers and width of a few tens of micrometers (Figure 8 a and Figure S60). For FTP10, both 3D networks of interwoven nanofibres and long helicoidal fibers are formed (Figure $\underline{8} \mathrm{~b}$ and Figure S60), though the fibers appear much thinner than those in CTP12 xerogels, irrespective of the solvents. Interestingly, in mixed solvents, containing "good" (toluene) and "poor" (ethanol) solvents, it was found that each representative compound, including LTP10 (using dichloromethane instead of toluene) aggregates, and exhibits stable, complex networks of intermingled long fibers (Figure $\underline{8} \mathrm{c}-\mathrm{e}$ and Figure S61).

Semiconducting Properties Self-organized columnar nanostructures consisting of two $\pi$-extended polycyclic aromatic hydrocarbons connected with carbazole, fluorene, and fluorenone moieties can be imagined as potentially microscopic supramolecular cables for charge carrier hopping pathways. Transient photocurrent time-of-flight (TOF) technique is a unique, accurate, direct and relatively simple method to measure charge carrier mobility of organic semiconductors with a very long charge hopping pathway through a distance of 15 to $20 \mu \mathrm{m}$ along the $\pi-\pi$ overlapping columns stacked by thousands of columnar molecules, very similar to their situations in electronic devices (from a few $\mu \mathrm{m}$ to $50 \mu \mathrm{m})$. We have investigated the photoconductive properties of four synthesized columnar mesogens with carbazole, fluorene, and fluorenone as central linking cores, respectively, by using the above mentioned TOF method, and the results are showed in Figure $\underline{9}$, and in more detail in supplementary information (Figures S67-S76 and Tables S7-S13).
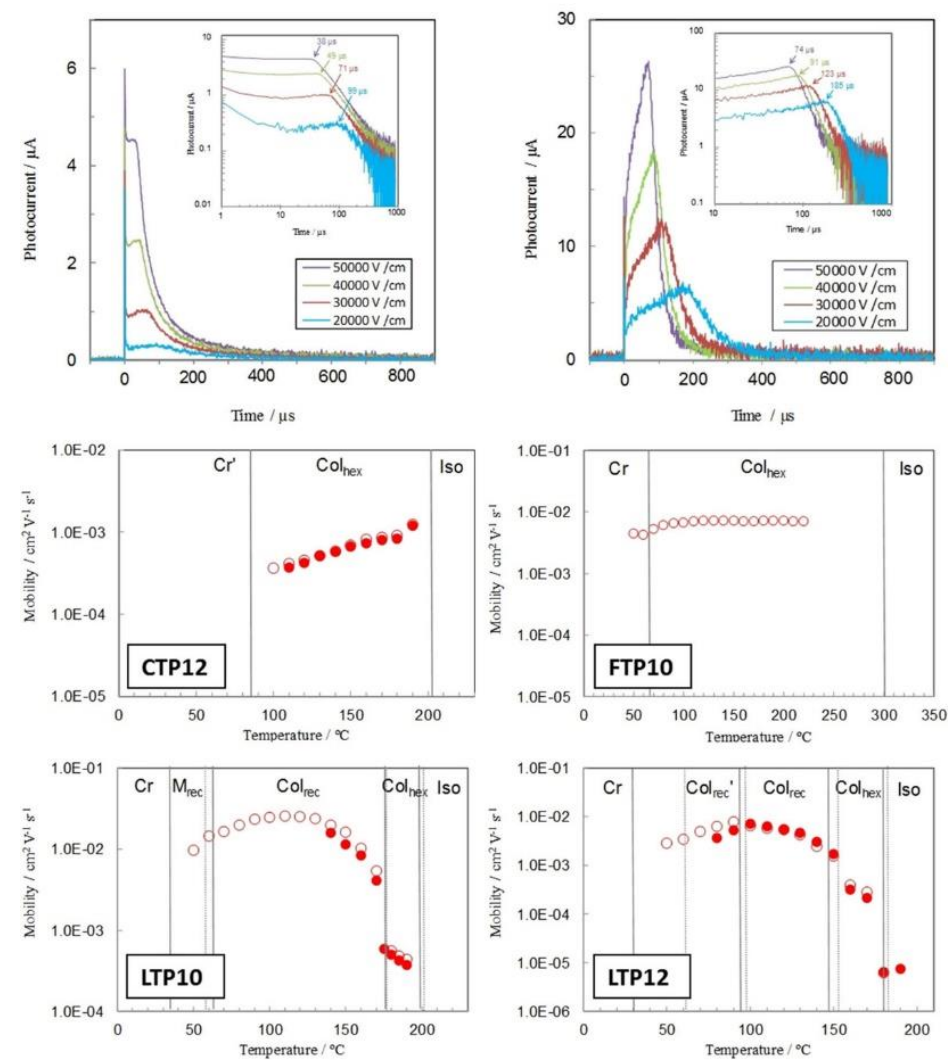

Figure 9. (Top) Samples of transient photocurrent decay curves of hole on cooling run in the Col hex phases for CTP12, at $160^{\circ} \mathrm{C}$, and for LTP10, at $190^{\circ} \mathrm{C}$; the insets show log-log plot, and the transit time at various electric field $\left(2-5 \times 10^{4} \mathrm{Vcm}^{-1}\right)$ was labeled. (Bottom) Temperature dependence of charge carrier mobility for CTP12, FTP10, LTP10, and LTP12 on cooling (open circle) and heating (close circle). 
The transient photocurrent decay curves are all in good shape and non-dispersive, demonstrating the high purity of these molecular semiconductors and thermal stability and excellent homeotropic alignment behavior in ITO cells. CTP12 with carbazole linkage shows a hole mobility of ca. $1.3 \times 10^{-3}$ $\mathrm{cm}^{-2} \mathrm{~V}^{-1} \mathrm{~s}^{-1}$ at $190^{\circ} \mathrm{C}$ in the Col hex phase, which substantially decreases to $4.2 \times 10^{-4} \mathrm{~cm}^{-2} \mathrm{~V}^{-1} \mathrm{~s}^{-1}$ on cooling, within the same range of $10^{-4}-10^{-3} \mathrm{~cm}^{-2} \mathrm{~V}^{-1} \mathrm{~s}^{-1}$ exhibited by the well-known triphenylene discogens, $\underline{34}$ reflecting the formation of fairly ordered $1 \mathrm{D} \pi$-stacked nanostructures in the $\mathrm{Col}_{\text {hex }}$ phase. The photoconductive mobility of CTP12 was fully reversible in successive heating and cooling runs, demonstrating that this carbazole-connected triphenylenes core is a good semiconducting columnar mesogen. On the contrary, FTP10 with a fluorenone linkage which has less alkyl chain in the core part shows higher hole mobility rate than CTP12, with a value of ca. $7.3 \times 10^{-3} \mathrm{~cm}^{-2} \mathrm{~V}^{-1} \mathrm{~s}^{-1}$ over the entire mesomorphic range ( $\mathrm{Col}_{\text {hex }}$ ) in the cooling cycle, decreasing down to $4.3 \times 10^{-3} \mathrm{~cm}^{-2} \mathrm{~V}^{-1} \mathrm{~s}^{-1}$ at the transition to the crystalline phase. Both LTP10 and LTP12 compounds, with fluorene linkage, show low hole mobility values of ca. (4.4-5.6) $\times 10^{-4} \mathrm{~cm}^{-2} \mathrm{~V}^{-1} \mathrm{~s}^{-1}$ and $(2.9-4.0) \times 10^{-4} \mathrm{~cm}^{-2} \mathrm{~V}^{-1} \mathrm{~s}^{-1}$, respectively, in the high temperature $\mathrm{Col}_{\text {hex }}$ phase. However, on cooling in the $\mathrm{Col}_{\text {rec }}$ phases, the hole mobilities rise and reach $2.6 \times 10^{-2} \mathrm{~cm}^{-2} \mathrm{~V}^{-1} \mathrm{~s}^{-1}$ and $6.5 \times 10^{-3} \mathrm{~cm}^{-2} \mathrm{~V}^{-1} \mathrm{~s}^{-1}$ at $110^{\circ} \mathrm{C}$ and $100^{\circ} \mathrm{C}$, respectively. On subsequent cooling LTP10 and LTP12 in the lower temperature $\mathrm{M}_{\text {rec }}$ and Colrec' phases, the hole mobilities decrease to $9.8 \times 10^{-3} \mathrm{~cm}^{-2} \mathrm{~V}^{-1} \mathrm{~s}^{-1}$ and $2.9 \times 10^{-3} \mathrm{~cm}^{-2} \mathrm{~V}^{-1} \mathrm{~s}^{-1}$, respectively, probably due to the charge trapping at grain boundary in poly domains of the highly ordered columnar mesophase.

In summary, these novel ditriphenylene columnar mesogens from carbazole, fluorenone, and fluorene show outstanding charge carrier transport properties mainly due to their larger $\pi$-electron systems especially for those fused with fluorenone and fluorene. The other factors contributing to the outstanding high TOF positive charge carrier mobility of LTP10/12 compared with other discotic mesogens ${ }^{35}$, 36 may include their higher ordered rectangular columnar (Col rec) mesophase (demonstrated by S/WAXS and POM results), as well as the decreased intracolumnar molecular dynamics by the lateral substitution of dimethyl groups on the fluorene core.

\section{Conclusions}

Several butterfly-shaped columnar liquid crystals featuring two triphenylenes fused with a central carbazole, fluorenone, and fluorene molecular moiety, respectively, have been synthesized. Their facile and straightforward synthetic strategy was accomplished by the Suzuki-Miyaura cross-coupling and Scholl oxidative cyclodehydrogenation tandem reactions. The polar CTP and FTP series display a single and broad mesophase, $\mathrm{Col}_{\text {hex, }}$ with very high clearing temperatures. The dimethyl terms of the LTP series show a rich self-organizational behavior including both rectangular ( $\mathrm{Col}_{\text {rec }}$ ) and hexagonal (Col hex) columnar mesophases. CTP and LTP in solution exhibit blue-light photoluminescence with absolute quantum yield of $27 \%$ and $70 \%$ respectively; while FTP solution emits yellow-light due to the intramolecular charge transfer (ICT), with absolute quantum efficiency of $28 \%$. CTP forms organogel in non-polar solvents; while polar mesogens FTP strongly gelate both polar and non-polar organic solvents; however, LTP cannot form organo-gel in in single solvent, but entangled fibrous networks emerged in mixture of good/poor solvents. Photocurrent time-of-flight results show that all compounds display hole mobility. In particular, LTP compounds show a hole mobility jump from (4.45.6) $\times 10^{-4} \mathrm{~cm}^{2} \mathrm{~V}^{-1} \mathrm{~s}^{-1}$, in the Col hex, up to almost $0.03 \mathrm{~cm}^{2} \mathrm{~V}^{-1} \mathrm{~s}^{-1}$ (LTP10) in the lower temperature higher ordered phase, due to large $\pi-\pi$ overlaps.

We believe that this generic synthetic strategy can be applied to other suitable electronically active molecular blocks in order to ease the construction and expand further the growing variety of more 
complex annulated $\pi$-extended optoelectronic materials with potential applications in various electronic film devices.

\section{Experimental Section}

All solvents and commercial reagents were used without further purification. The synthesis of the precursors ( $\mathbf{1} \mathbf{a}-\mathbf{e}, \mathbf{2} \mathbf{a}-\mathbf{e}, \mathbf{3} \mathbf{a}-\mathbf{b}$, and $\mathbf{4} \mathbf{a}-\mathbf{k}$, Scheme $\underline{1}$ and Scheme S1) and characterization (NMR, Figures S1-S43, HRMS, Figures S45-S55) are shown in the supplementary information.

(CTP12) 10-Octyl-2,3,6,7,13,14,17,18-octakis(dodecyloxy)-10H-diphenanthro[9,10- $b$ : 9',10'h]carbazole. To a $100 \mathrm{~mL}$ round bottom flask, 4 a $(0.18 \mathrm{~g}, 0.09 \mathrm{mmol})$, then $\mathrm{FeCl}_{3}(0.09 \mathrm{~g}, 0.52 \mathrm{mmol})$ in dichloromethane $(60 \mathrm{~mL})$ and nitromethane $(5 \mathrm{~mL})$ were added, and stirred at room temperature. The reaction was tracked every 15 minutes. When the reaction was finished, the mixture was quenched by addition of cold methanol. Then, it was extracted with dichloromethane, dried over $\mathrm{MgSO}_{4}$, filtered and solvent removed by rotary evaporation. Purification with silica gel column chromatography (toluene/petroleum ether $=1: 1 \mathrm{v} / \mathrm{v}$ ) and recrystallization with ethanol and ethyl acetate gave a yellow-green solid, CTP12 (0.09 g, $50 \%) .{ }^{1} \mathrm{H}$ NMR (CDCl, TMS, $\left.400 \mathrm{MHz}\right) \delta(\mathrm{ppm}): 9.34$ $(\mathrm{s}, 2 \mathrm{H}, \mathrm{ArH}), 8.33(\mathrm{~s}, 2 \mathrm{H}, \mathrm{ArH}), 8.29(\mathrm{~s}, 2 \mathrm{H}, \mathrm{ArH}), 8.15(\mathrm{~s}, 2 \mathrm{H}, \mathrm{ArH}), 7.88(\mathrm{~s}, 4 \mathrm{H}, \mathrm{ArH}), 4.58-4.61(\mathrm{~m}, 2 \mathrm{H}$, $\left.\mathrm{NCH}_{2}\right), 4.37-4.42\left(\mathrm{~m}, 4 \mathrm{H}, \mathrm{OCH}_{2}\right), 4.25-4.33\left(\mathrm{~m}, 12 \mathrm{H}, \mathrm{OCH}_{2}\right), 1.96-2.14\left(\mathrm{~m}, 18 \mathrm{H}, \mathrm{CH}_{2}\right), 1.62-1.67(\mathrm{~m}$, $\left.12 \mathrm{H}, \mathrm{CH}_{2}\right), 1.25-1.45\left(\mathrm{~m}, 142 \mathrm{H}, \mathrm{CH}_{2}\right), 0.87\left(\mathrm{t}, \mathrm{J}=8.0 \mathrm{~Hz}, 27 \mathrm{H}, \mathrm{CH}_{3}\right) .{ }^{13} \mathrm{C} \mathrm{NMR}\left(\mathrm{CDCl}_{3}, \mathrm{TMS}, 100 \mathrm{MHz}\right) \delta$ (ppm): 149.72, 149.21, 148.87, 148.78, 141.75, 128.59, 125.06, 127.71, 124.10, 123.19, 123.09, 122.33, 114.59, 108.49, 108.14, 107.63, 107.29, 100.31, 70.17, 70.02, 69.78, 69.58, 31.94, 31.82, 29.80, 29.76, $29.73,29.71,29.67,29.63,29.62,29.59,29.50,29.44,29.40,29.31,28.63,27.52,26.30,26.26,22.70$, 22.63, 14.12, 14.04. HRMS m/s (MALDI): [M] ${ }^{+}$Calcd. for $\mathrm{C}_{140} \mathrm{H}_{229} \mathrm{NO}_{8}: 2053.7577$; Found: 2053.7578. Elemental analysis: Calcd. for $\mathrm{C}_{140} \mathrm{H}_{229} \mathrm{NO}_{8}$ : C $81.85 \%, \mathrm{H} 11.24 \%$, N 0.68 \%; Found: C $81.94 \%$, H $11.30 \%$, N, $0.30 \%$.

(CTP14) 10-Octyl-2,3,6,7,13,14,17,18-octakis(tetradecyloxy)-10H-diphenanthro[9,10-b : 9',10'h]carbazole. As above. (4 b) $(0.21 \mathrm{~g}, 0.09 \mathrm{mmol}), \mathrm{FeCl}_{3}(0.09 \mathrm{~g}, 0.55 \mathrm{mmol})$ in dichloromethane $(60 \mathrm{~mL})$ and nitromethane $(5 \mathrm{~mL})$. Purification by silica gel column chromatography (toluene/petroleum ether=1:1 v/v) and recrystallization with ethanol and ethyl acetate resulted in a yellow-green solid CTP14 (0.1 g, yield $47 \%) .{ }^{1} \mathrm{H} N M R\left(\mathrm{CDCl}_{3}, \mathrm{TMS}, 400 \mathrm{MHz}\right) \delta(\mathrm{ppm}): 9.32(\mathrm{~s}, 2 \mathrm{H}, \mathrm{ArH}), 8.32(\mathrm{~s}, 2 \mathrm{H}, \mathrm{ArH})$, $8.27(\mathrm{~s}, 2 \mathrm{H}, \mathrm{ArH}), 8.13(\mathrm{~s}, 2 \mathrm{H}, \mathrm{ArH}), 7.87(\mathrm{~s}, 4 \mathrm{H}, \mathrm{ArH}), 4.55-4.58\left(\mathrm{~m}, 2 \mathrm{H}, \mathrm{NCH}_{2}\right), 4.42\left(\mathrm{t}, \mathrm{J}=8 \mathrm{~Hz}, 4 \mathrm{H}, \mathrm{OCH}_{2}\right)$, 4.25-4.31 (m, 12H, OCH $\left.\mathrm{OCH}_{2}\right), 2.10-2.13\left(\mathrm{~m}, 2 \mathrm{H}, \mathrm{CH}_{2}\right), 1.98-2.03\left(\mathrm{~m}, 16 \mathrm{H}, \mathrm{CH}_{2}\right), 1.69-1.67\left(\mathrm{~m}, 18 \mathrm{H}, \mathrm{CH}_{2}\right)$,

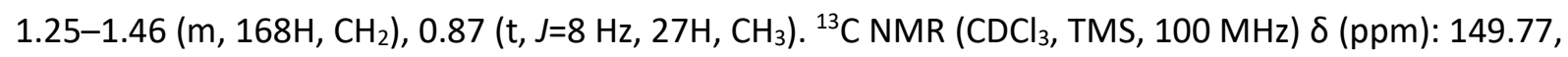
$149.26,148.91,148.33,141.77,128.62,125.09,124.75,124.15,123.21,123.13,122.36,114.60$, 108.60, 108.24, 107.73, 107.39, 100.33, 70.20, 70.06, 69.82, 69.62, 31.92, 31.81, 29.79, 29.77, 29.74, $29.72,29.70,29.68,29.65,29.61,29.60,29.58,29.51,29.43,29.37,29.29,28.62,27.51,26.29,26.25$ 22.68, 22.61, 14.09, 14.01. HRMS m/s (MALDI): [M] ${ }^{+}$. Calcd. for $\mathrm{C}_{156} \mathrm{H}_{261} \mathrm{NO}_{8}$ : 2278.0081; Found: 2278.0078. Elemental analysis: Calcd. for $\mathrm{C}_{156} \mathrm{H}_{261} \mathrm{NO}_{8}$ : C $82.22 \%, \mathrm{H} 11.55 \%, \mathrm{~N} 0.61 \%$; Found: $\mathrm{C}$ $81.98 \%, 11.22 \%, \mathrm{~N}, 0.30 \%$.

(FTP10) 2,3,6,7,12,13,16,17-Octakis(decyloxy)-20H-cyclopenta[1,2-b : 3,4- $b^{\prime}$ ]ditriphenylen-20-one. As above. $4 \mathrm{c}(0.11 \mathrm{~g}, 0.07 \mathrm{mmol}), \mathrm{FeCl}_{3}(0.06 \mathrm{~g}, 0.39 \mathrm{mmol})$, in chloroform $(60 \mathrm{~mL})$ and nitromethane $(5$ $\mathrm{mL}$ ). Silica gel column chromatography (toluene/petroleum ether $=1: 2 \mathrm{v} / \mathrm{v}$ ). Recrystallization toluene

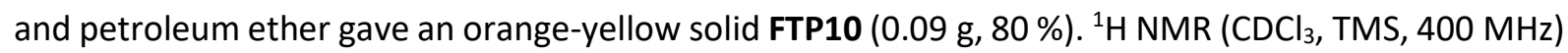
$\delta$ (ppm): 8.35 (s, 2H, ArH), 8.18 (s, 2H, ArH), 7.91 (s, 2H, ArH), 7.56 (s, 2H, ArH), $7.43(\mathrm{~s}, 2 \mathrm{H}, \operatorname{ArH}), 7.41$ $(\mathrm{s}, 2 \mathrm{H}, \mathrm{ArH}), 4.36\left(\mathrm{t}, J=8.0 \mathrm{~Hz}, 4 \mathrm{H}, \mathrm{OCH}_{2}\right), 4.10\left(\mathrm{t}, \mathrm{J}=4.0 \mathrm{~Hz}, 12 \mathrm{H}, \mathrm{OCH}_{2}\right), 1.92-2.07\left(\mathrm{~m}, 16 \mathrm{H}, \mathrm{CH}_{2}\right), 1.62-$ 
$1.72\left(\mathrm{~m}, 10 \mathrm{H}, \mathrm{CH}_{2}\right), 1.25-1,48\left(\mathrm{~m}, 102 \mathrm{H}, \mathrm{CH}_{2}\right), 0.90$ (t, J=8.0 Hz, 24H, $\left.\mathrm{CH}_{3}\right) . \mathrm{HRMS} \mathrm{m} / \mathrm{s}$ (MALDI): [M] ${ }^{+}$ Calcd. for $\mathrm{C}_{117} \mathrm{H}_{180} \mathrm{O}_{9}$ : 1730.3661; Found: 1730.3660. Elemental analysis: Calcd. for $\mathrm{C}_{117} \mathrm{H}_{180} \mathrm{O}_{9}$ : C $81.20 \%$, H $10.48 \%$; Found: C $80.96 \%$, H $10.59 \%$.

(FTP12) 2,3,6,7,12,13,16,17-Octakis(dodecyloxy)-20H-cyclopenta[1,2-b : 3,4-b']ditriphenylen-20-one. As above. $4 \mathrm{~d}(0.14 \mathrm{~g}, 0.07 \mathrm{mmol}), \mathrm{FeCl}_{3}(0.07 \mathrm{~g}, 0.43 \mathrm{mmol})$ in chloroform $(60 \mathrm{~mL})$ and nitromethane $(5 \mathrm{~mL})$. Silica gel column chromatography (toluene/petroleum ether $=1: 2 \mathrm{v} / \mathrm{v}$ ). Recrystallization from ethyl acetate and ethanol (toluene and petroleum ether) gave an orange-yellow solid FTP12 $(0.07 \mathrm{~g}$, $47 \%) .{ }^{1} \mathrm{H} \mathrm{NMR}\left(\mathrm{CDCl}_{3}, \mathrm{TMS}, 400 \mathrm{MHz}\right) \delta(\mathrm{ppm}): 8.41$ (s, 2H, ArH), $8.24(\mathrm{~s}, 2 \mathrm{H}, \mathrm{ArH}), 7.94(\mathrm{~s}, 2 \mathrm{H}, \mathrm{ArH})$, $7.61(\mathrm{~s}, 2 \mathrm{H}, \mathrm{ArH}), 7.47(\mathrm{~s}, 2 \mathrm{H}, \mathrm{ArH}), 7.45(\mathrm{~s}, 2 \mathrm{H}, \mathrm{ArH}), 4.37(\mathrm{t}, \mathrm{J}=8.0 \mathrm{~Hz}, 4 \mathrm{H}, \mathrm{OCH})_{2}, 4.09-4.15(\mathrm{~m}, 12 \mathrm{H}$, $\left.\mathrm{OCH}_{2}\right), 1.94-2.05\left(\mathrm{~m}, 16 \mathrm{H}, \mathrm{CH}_{2}\right), 1.61-1.70\left(\mathrm{~m}, 16 \mathrm{H}, \mathrm{CH}_{2}\right), 1.30-1,45\left(\mathrm{~m}, 128 \mathrm{H}, \mathrm{CH}_{2}\right), 0.89(\mathrm{t}, \mathrm{J}=8.0 \mathrm{~Hz}$, $24 \mathrm{H}, \mathrm{CH}_{3}$ ). HRMS m/s (MALDI): [M+H] ${ }^{+}$Calcd. for $\mathrm{C}_{133} \mathrm{H}_{212} \mathrm{O}_{9}$ : 1955.6243; Found 1955.6264. Elemental analysis: Calcd. for $\mathrm{C}_{133} \mathrm{H}_{212} \mathrm{O}_{9}$ : C $81.71 \%, \mathrm{H} 10.93 \%$; Found: C $82.06 \%, \mathrm{H} 11.23 \%$.

(LTP5) 2,3,6,7,12,13,16,17-Octakis(pentyloxy)-20,20-dimethyl-20H-cyclopenta[1,2-b : 3,4$b^{\prime}$ ]ditriphenylene. As above. $4 \mathrm{e}(0.1 \mathrm{~g}, 0.08 \mathrm{mmol})$, dichloromethane $(40 \mathrm{~mL})$, nitromethane $(4 \mathrm{~mL})$, $\mathrm{FeCl}_{3}(0.70 \mathrm{~g}, 0.42 \mathrm{mmol})$. Silica gel column chromatography (dichloromethane/petroleum ether=1: 1 $\mathrm{v} / \mathrm{v})$ and recrystallization with ethanol and ethyl acetate to obtain LTP5 as a white solid $(0.095 \mathrm{~g}$, 93.8 \%). ${ }^{1} \mathrm{H}$ NMR (CDCl $\left., \mathrm{TMS}, 400 \mathrm{MHz}\right) \delta$ (ppm): 9.00 (s, 2H, ArH), $8.52(\mathrm{~s}, 2 \mathrm{H}, \mathrm{ArH}), 8.29(\mathrm{~s}, 2 \mathrm{H}, \mathrm{ArH})$, $8.11(\mathrm{~s}, 2 \mathrm{H}, \mathrm{ArH}), 7.87(\mathrm{~s}, 4 \mathrm{H}, \mathrm{ArH}), 4.39\left(\mathrm{t}, \mathrm{J}=5.6 \mathrm{~Hz}, 4 \mathrm{H}, \mathrm{OCH}_{2}\right), 4.29\left(\mathrm{t}, J=3.6 \mathrm{~Hz}, 12 \mathrm{H}, \mathrm{OCH}_{2}\right), 1.97-2.07$ $\left(\mathrm{m}, 16 \mathrm{H}, \mathrm{CH}_{2}\right), 1.84\left(\mathrm{~s}, 6 \mathrm{H}, 2 \mathrm{CH}_{3}\right), 1.49-1.62\left(\mathrm{~m}, 32 \mathrm{H}, \mathrm{CH}_{2}\right), 1.00\left(\mathrm{t}, \mathrm{J}=1.6 \mathrm{~Hz}, 24 \mathrm{H}, \mathrm{CH}_{3}\right) .{ }^{13} \mathrm{C} \mathrm{NMR}\left(\mathrm{CDCl}_{3}\right.$, TMS, $100 \mathrm{MHz}) \delta$ (ppm): 152.28, 152.20, 149.75, 149.61, 148.93, 137.75, 137.69, 137.62, 128.75, 124.17, 116.53, 113.98, 108.56, 107.59, 107.36, 106.98, 106.84, 70.22, 69.64, 69.43, 46.82, 29.32, $29.21,29.17,28.79,28.43,28.41,22.64,22.63,22.61,14.16,14.14$. HRMS m/z (100 \%) (MALDI): [M] ${ }^{+}$ calcd for $\mathrm{C}_{79} \mathrm{H}_{106} \mathrm{O}_{8}$ 1182.7888; Found 1182.7888. Elemental analysis: Calcd. for $\mathrm{C}_{79} \mathrm{H}_{106} \mathrm{O}_{8}: \mathrm{C} 80.16 \%, \mathrm{H}$ $9.03 \%$. Found: C $79.80 \%, \mathrm{H} 8.70 \%$.

(LTP8)

2,3,6,7,12,13,16,17-Octakis(octyloxy)-20,20-dimethyl-20H-cyclopenta[1,2-b : 3,4$b^{\prime}$ ]ditriphenylene. As above. $4 \mathrm{f}(0.20 \mathrm{~g}, 0.13 \mathrm{mmol})$, dichloromethane $(60 \mathrm{~mL})$, nitromethane $(5 \mathrm{~mL})$, $\mathrm{FeCl}_{3}(0.11 \mathrm{~g}, 0.66 \mathrm{mmol})$. Silica gel column (dichloromethane/petroleum ether=1:2 $\mathrm{v} / \mathrm{v}$ ) and recrystallization with ethanol and ethyl acetate gave LTP8 as a white solid $(0.16 \mathrm{~g}, 80.4 \%) .{ }^{1} \mathrm{H}$ NMR $\left(\mathrm{CDCl}_{3}, \mathrm{TMS}, 400 \mathrm{MHz}\right) \delta(\mathrm{ppm}): 9.00(\mathrm{~s}, 2 \mathrm{H}, \mathrm{ArH}), 8.52(\mathrm{~s}, 2 \mathrm{H}, \mathrm{ArH}), 8.30(\mathrm{~s}, 2 \mathrm{H}, \mathrm{ArH}), 8.12(\mathrm{~s}, 2 \mathrm{H}, \mathrm{ArH})$, $7.88(\mathrm{~s}, 4 \mathrm{H}, \mathrm{ArH}), 4.32\left(\mathrm{t}, \mathrm{J}=6.4 \mathrm{~Hz}, 16 \mathrm{H}, \mathrm{OCH}_{2}\right), 1.94-2.04\left(\mathrm{~m}, 16 \mathrm{H}, \mathrm{CH}_{2}\right), 1.84\left(\mathrm{~s}, 6 \mathrm{H}, 2 \mathrm{CH}_{3}\right), 1.33-1.66$ $\left(\mathrm{m}, 80 \mathrm{H}, \mathrm{CH}_{2}\right), 0.91\left(\mathrm{t}, \mathrm{J}=8 \mathrm{~Hz}, 24 \mathrm{H}, \mathrm{CH}_{3}\right) .{ }^{13} \mathrm{C} \mathrm{NMR}\left(\mathrm{CDCl}_{3}, \mathrm{TMS}, 100 \mathrm{MHz}\right) \delta(\mathrm{ppm}): 152.25,149.68$, $149.56,149.04,148.96,137.63,128.88,128.69,124.41,124.19,116.54,113.99,108.58,107.72$, 107.22, 106.96, 70.23, 69.76, 69.67, 69.51, 46.78, 31.92, 31.88, 29.68, 29.59, 29.56, 29.54, 29.53, $29.52,29.37,28.75,26.26,26.24,22.71,14.12$. HRMS m/z (100 \%) (MALDI): [M] ${ }^{+}$calcd for $\mathrm{C}_{103} \mathrm{H}_{154} \mathrm{O}_{8}$ 1520.1677; Found 1520.1668. Elemental analysis: Calcd. for $\mathrm{C}_{103} \mathrm{H}_{154} \mathrm{O}_{8}$ : $\mathrm{C} 81.37 \%$, H $10.21 \%$. Found: C $80.96 \%$, H $10.18 \%$.

(LTP10)

2,3,6,7,12,13,16,17-Octakis(decyloxy)-20,20-dimethyl-20H-cyclopenta[1,2-b : 3,4$b^{\prime}$ ]ditriphenylene. As above. $4 \mathrm{~g}(0.22 \mathrm{~g}, 0.13 \mathrm{mmol}), \mathrm{FeCl}_{3}(0.10 \mathrm{~g}, 0.63 \mathrm{mmol})$ in chloroform $(60 \mathrm{~mL})$ and nitromethane $(5 \mathrm{~mL}$ ). Silica gel column chromatography (dichloromethane/petroleum ether=1:2 $\mathrm{v} / \mathrm{v})$. Recrystallization from ethyl acetate and ethanol gave a white solid LTP10 (0.19 g, $88 \%) .{ }^{1} \mathrm{H}$ NMR $\left(\mathrm{CDCl}_{3}, \mathrm{TMS}, 400 \mathrm{MHz}\right) \delta(\mathrm{ppm}): 9.00(\mathrm{~s}, 2 \mathrm{H}, \mathrm{ArH}), 8.52(\mathrm{~s}, 2 \mathrm{H}, \mathrm{ArH}), 8.30(\mathrm{~s}, 2 \mathrm{H}, \mathrm{ArH}), 8.12(\mathrm{~s}, 2 \mathrm{H}, \mathrm{ArH})$, $7.88(\mathrm{~s}, 4 \mathrm{H}, \mathrm{ArH}), 4.27-4.40\left(\mathrm{~m}, 16 \mathrm{H}, \mathrm{OCH}_{2}\right), 1.95-2.06\left(\mathrm{~m}, 16 \mathrm{H}, \mathrm{CH}_{2}\right), 1.83\left(\mathrm{~s}, 6 \mathrm{H}, \mathrm{CH}_{3}\right), 1.60-1.68(\mathrm{~m}$,

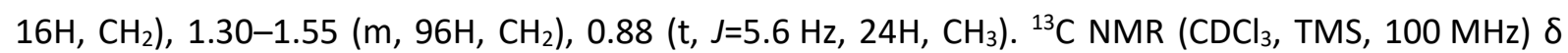
(ppm): 152.11, 149.58, 149.41, 148.96, 148.81, 137.60, 128.82, 128.66, 124.34, 124.24, 124.08, 116.49, 113.94, 108.39, 107.39, 107.09, 106.63, 70.15, 69.63, 69.36, 46.76, 31.99, 29.78, 29.70, 29.65, 29.63, 29.60, 29.55, 29.48, 29.46, 28.82, 26.30, 22.76, 14.18, 14.16. HRMS m/s (MALDI): [M]+. Calcd. for 
$\mathrm{C}_{119} \mathrm{H}_{186} \mathrm{O}_{8}:$ 1744.4181; Found: 1744.4180. Elemental analysis: Calcd. for $\mathrm{C}_{119} \mathrm{H}_{186} \mathrm{O}_{8}: \mathrm{C} 81.92 \%, \mathrm{H}$ $10.75 \%$; Found: C $81.94 \%$, H $10.51 \%$.

(LTP12) 2,3,6,7,12,13,16,17-Octakis(dodecyloxy)-20,20-dimethyl-20H-cyclopenta[1,2- $b: 3,4$ $b^{\prime}$ ]ditriphenylene. As above. $4 \mathrm{~h}(0.18 \mathrm{~g}, 0.09 \mathrm{mmol}), \mathrm{FeCl}_{3}(0.07 \mathrm{~g}, 0.46 \mathrm{mmol})$ in chloroform $(60 \mathrm{~mL})$ and nitromethane $(5 \mathrm{~mL})$. Silica gel column chromatography (dichloromethane/petroleum ether=1:2 $\mathrm{v} / \mathrm{v})$. Recrystallization from ethyl acetate and ethanol gave a white solid LTP12 (0.12 g, $66 \%) .{ }^{1} \mathrm{H}$ NMR $\left(\mathrm{CDCl}_{3}, \mathrm{TMS}, 400 \mathrm{MHz}\right) \delta(\mathrm{ppm}): 9.00(\mathrm{~s}, 2 \mathrm{H}, \mathrm{ArH}), 8.52(\mathrm{~s}, 2 \mathrm{H}, \mathrm{ArH}), 8.29(\mathrm{~s}, 2 \mathrm{H}, \mathrm{ArH}), 8.12(\mathrm{~s}, 2 \mathrm{H}, \mathrm{ArH})$, $7.87(\mathrm{~s}, 4 \mathrm{H}, \mathrm{ArH}), 4.28-4.40\left(\mathrm{~m}, 16 \mathrm{H}, \mathrm{OCH}_{2}\right), 1.93-2.05\left(\mathrm{~m}, 16 \mathrm{H}, \mathrm{CH}_{2}\right), 1.83\left(\mathrm{~s}, 6 \mathrm{H}, \mathrm{CH}_{3}\right), 1.25-1.64(\mathrm{~m}$, $\left.144 \mathrm{H}, \mathrm{CH}_{2}\right), 0.86\left(\mathrm{t}, \mathrm{J}=6.4 \mathrm{~Hz}, 24 \mathrm{H}, \mathrm{CH}_{3}\right) .{ }^{13} \mathrm{C} \mathrm{NMR}\left(\mathrm{CDCl}_{3}, \mathrm{TMS}, 100 \mathrm{MHz}\right) \delta(\mathrm{ppm}): 149.62,147.05$, $146.90,146.41,146.30,135.05,126.28,126.10,121.79,121.73,121.54,113.96,111.40,105.85$, 104.95, 104.52, 104.19, 67.59, 67.09, 67.05, 66.86, 44.20, 29.40, 27.25, 27.22, 27.20, 27.16, 27.13, 27.06, 27.04, 27.01, 26.95, 26.86, 26.21, 23.73, 23.71, 20.17, 11.60, 11.58. HRMS m/s (MALDI): [M] $]^{+}$ Calcd. for $\mathrm{C}_{135} \mathrm{H}_{218} \mathrm{O}_{8}$ : 1968.6685; Found: 1968.6686. Elemental analysis: Calcd. for $\mathrm{C}_{135} \mathrm{H}_{218} \mathrm{O}_{8}: \mathrm{C}$ $82.34 \%$, H $11.16 \%$; Found: C $82.43 \%$, H $11.30 \%$.

(LTP58) 2,3,6,7,12,13,16,17-Octakis(pentyloxy)-20,20-dioctyl-20H-cyclopenta[1,2-b:3,4$b^{\prime}$ ]ditriphenylene. As above. 4 i (0.18 g, $\left.0.13 \mathrm{mmol}\right)$, dichloromethane $(50 \mathrm{~mL})$, nitromethane $(5 \mathrm{~mL})$, $\mathrm{FeCl}_{3}(0.11 \mathrm{~g}, 0.65 \mathrm{mmol})$. Silica gel column (dichloromethane/petroleum ether=1:1.5 v/v) and recrystallization with ethanol and ethyl acetate gave LTP58 as a white solid $(0.14 \mathrm{~g}, 80.0 \%) .{ }^{1} \mathrm{H}$ NMR $\left(\mathrm{CDCl}_{3}, \mathrm{TMS}, 400 \mathrm{MHz}\right) \delta(\mathrm{ppm}): 9.00(\mathrm{~s}, 2 \mathrm{H}, \mathrm{ArH}), 8.41(\mathrm{~s}, 2 \mathrm{H}, \mathrm{ArH}), 8.30(\mathrm{~s}, 2 \mathrm{H}, \mathrm{ArH}), 8.12(\mathrm{~s}, 2 \mathrm{H}, \mathrm{ArH})$, $7.89(\mathrm{~s}, 4 \mathrm{H}, \mathrm{ArH}), 4.31\left(\mathrm{t}, J=6.8 \mathrm{~Hz}, 16 \mathrm{H}, \mathrm{OCH}_{2}\right), 2.28\left(\mathrm{t}, J=7.2 \mathrm{~Hz}, 4 \mathrm{H}, 2 \mathrm{CH}_{2}\right), 1.94-2.05\left(\mathrm{~m}, 16 \mathrm{H}, \mathrm{CH}_{2}\right)$, 1.48-1.62 (m, 40H, $\left.\mathrm{CH}_{2}\right), 1.01-1.08\left(\mathrm{~m}, 16 \mathrm{H}, \mathrm{CH}_{2}\right), 0.99\left(\mathrm{t}, \mathrm{J}=1.2 \mathrm{~Hz}, 24 \mathrm{H}, \mathrm{CH}_{3}\right), 0.70(\mathrm{t}, \mathrm{J}=2.8 \mathrm{~Hz}, 6 \mathrm{H}$, $\left.\mathrm{CH}_{3}\right) .{ }^{13} \mathrm{C} \mathrm{NMR}\left(\mathrm{CDCl}_{3}, \mathrm{TMS}, 100 \mathrm{MHz}\right) \delta$ (ppm): 149.69, 149.64, 149.39, 149.08, 149.04, 139.66, 128.87, $128.58,124.47,124.35,124.26,116.59,113.69,108.42$, 108.03, 107.40, 107.09, 70.12, 70.10, 69.85, 69.75, 69.57, 55.10, 41.75, 31.74, 30.06, 29.56, 29.50, 29.25, 29.21, 29.20, 29.16, 29.12, 28.42, 28.40, 28.38, 28.37, 25.92, 25.89, 23.98, 22.70, 22.65, 22.63, 22.59, 22.57, 22.48, 14.15, 14.12, 14.08, 13.96 . HRMS m/z (100 \%) (MALDI): [M] ${ }^{+}$calcd for $\mathrm{C}_{93} \mathrm{H}_{134} \mathrm{O}_{8} 1380.0112$; Found 1380.0090. Elemental analysis: Calcd. for $\mathrm{C}_{93} \mathrm{H}_{134} \mathrm{O}_{8}$ : C $80.94 \%$, H $9.79 \%$. Found: C $80.58 \%$, H $9.86 \%$.

(LTP88)

2,3,6,7,12,13,16,17-Octakis(octyloxy)-20,20-dioctyl-20H-cyclopenta[1,2-b : 3,4$b^{\prime}$ ]ditriphenylene. As above. $4 \mathrm{j}(0.25 \mathrm{~g}, 0.15 \mathrm{mmol})$, dichloromethane $(70 \mathrm{~mL})$, nitromethane $(5 \mathrm{~mL})$, $\mathrm{FeCl}_{3}(0.12 \mathrm{~g}, 0.73 \mathrm{mmol})$. Silica gel column (dichloromethane/petroleum ether=1:2 v/v) and recrystallization from ethanol and ethyl acetate gave LTP88 as a white solid. (0.18 g, 73.1 \%). ${ }^{1} \mathrm{H}$ NMR $\left(\mathrm{CDCl}_{3}, \mathrm{TMS}, 400 \mathrm{MHz}\right) \delta(\mathrm{ppm}): 9.00(\mathrm{~s}, 2 \mathrm{H}, \mathrm{ArH}), 8.41(\mathrm{~s}, 2 \mathrm{H}, \mathrm{ArH}), 8.31(\mathrm{~s}, 2 \mathrm{H}, \mathrm{ArH}), 8.12(\mathrm{~s}, 2 \mathrm{H}, \mathrm{ArH})$, $7.89(\mathrm{~s}, 4 \mathrm{H}, \mathrm{ArH}), 4.31\left(\mathrm{t}, \mathrm{J}=1.2 \mathrm{~Hz}, 16 \mathrm{H}, \mathrm{OCH}_{2}\right), 2.28\left(\mathrm{t}, \mathrm{J}=1.2 \mathrm{~Hz}, 4 \mathrm{H}, 2 \mathrm{CH}_{2}\right), 1.93-2.05\left(\mathrm{~m}, 16 \mathrm{H}, \mathrm{CH}_{2}\right)$, 1.00-1.63 (m, 104H, CH $\mathrm{CH}_{2}, 0.91\left(\mathrm{t}, \mathrm{J}=2 \mathrm{~Hz}, 24 \mathrm{H}, \mathrm{CH}_{3}\right), 0.70\left(\mathrm{t}, \mathrm{J}=7.2 \mathrm{~Hz}, 6 \mathrm{H}, \mathrm{CH}_{3}\right) .{ }^{13} \mathrm{C} \mathrm{NMR}\left(\mathrm{CDCl}_{3}, \mathrm{TMS}\right.$, $100 \mathrm{MHz}$ ) $\delta$ (ppm): 149.65, 149.62, 149.39, 149.10, 149.05, 139.66, 128.87, 128.58, 124.47, 124.36, 124.30, 124.27, 116.59, 113.70, 108.37, 108.08, 107.46, 107.15, 70.09, 69.91, 69.79, 69.62, 55.11, 41.76, 31.91, 31.87, 31.75, 30.06, 29.61, 29.58, 29.56, 29.52, 29.49, 29.47, 29.38, 29.35, 29.22, 29.16, 26.27, 26.24, 26.21, 23.98, 22.70, 22.48, 14.13, 14.11, 13.96. HRMS m/z (100 \%) (MALDI): [M] ${ }^{+}$calcd for $\mathrm{C}_{117} \mathrm{H}_{182} \mathrm{O}_{8}$ 1716.3868; Found 1716.3863. Elemental analysis: Calcd. for $\mathrm{C}_{117} \mathrm{H}_{182} \mathrm{O}_{8}: \mathrm{C} 81.86 \%, \mathrm{H}$ $10.69 \%$. Found: C $81.48 \%$, H $10.74 \%$.

(LTP108)

2,3,6,7,12,13,16,17-Octakis(decyloxy)-20,20-dioctyl-20H-cyclopenta[1,2-b : 3,4$b^{\prime}$ ]ditriphenylene. As above. $4 \mathbf{k}(0.2 \mathrm{~g}, 0.10 \mathrm{mmol})$, dichloromethane $(50 \mathrm{~mL})$, nitromethane $(5 \mathrm{~mL})$, $\mathrm{FeCl}_{3}(0.08 \mathrm{~g}, 0.51 \mathrm{mmol})$. Silica gel column (dichloromethane/petroleum ether=1:1.5 v/v) and recrystallization with ethanol and ethyl acetate gave $\mathbf{L} 108(0.12 \mathrm{~g}, 60.1 \%)$ as a white solid. ${ }^{1} \mathrm{H}$ NMR $\left(\mathrm{CDCl}_{3}, \mathrm{TMS}, 400 \mathrm{MHz}\right) \delta(\mathrm{ppm}): 8.99(\mathrm{~s}, 2 \mathrm{H}, \mathrm{ArH}), 8.41(\mathrm{~s}, 2 \mathrm{H}, \mathrm{ArH}), 8.31(\mathrm{~s}, 2 \mathrm{H}, \mathrm{ArH}), 8.12(\mathrm{~s}, 2 \mathrm{H}, \mathrm{ArH})$, $7.90(\mathrm{~s}, 4 \mathrm{H}, \mathrm{ArH}), 4.31\left(\mathrm{t}, \mathrm{J}=0.8 \mathrm{~Hz}, 16 \mathrm{H}, \mathrm{OCH}_{2}\right), 2.28\left(\mathrm{t}, \mathrm{J}=0.4 \mathrm{~Hz}, 4 \mathrm{H}, 2 \mathrm{CH}_{2}\right), 1.93-2.05\left(\mathrm{~m}, 16 \mathrm{H}, \mathrm{CH}_{2}\right)$, 
1.53-1.67 (m, 24H, $\left.\mathrm{CH}_{2}\right), 1.00-1.45\left(\mathrm{~m}, 112 \mathrm{H}, \mathrm{CH}_{2}\right), 0.89\left(\mathrm{t}, \mathrm{J}=6.8 \mathrm{~Hz}, 24 \mathrm{H}, \mathrm{CH}_{3}\right), 0.70(\mathrm{t}, J=7.2 \mathrm{~Hz}, 6 \mathrm{H}$, $\left.\mathrm{CH}_{3}\right) .{ }^{13} \mathrm{CNMR}\left(\mathrm{CDCl}_{3}, \mathrm{TMS}, 100 \mathrm{MHz}\right) \delta$ (ppm): 149.65, 149.62, 149.39, 149.10, 149.05, 139.66, 128.87, 128.58, 124.47, 124.36, 124.30, 124.27, 116.59, 113.70, 108.37, 108.08, 107.46, 107.15, 70.09, 69.91, $69.79,69.62,55.11,41.76,31.91,31.87,31.75,30.06,29.61,29.58,29.56,29.52,29.49,29.47,29.38$, $29.35,29.22,29.16,26.27,26.24,26.21,23.98,22.70,22.48,14.13,14.11,13.96$. HRMS m/z (100\%) (MALDI): [M] ${ }^{+}$calcd for $\mathrm{C}_{133} \mathrm{H}_{214} \mathrm{O}_{8}$ 1940.6372; Found 1940.6363. Elemental analysis: Calcd. for $\mathrm{C}_{133} \mathrm{H}_{214} \mathrm{O}_{8}$ : C $82.29 \%$, H $11.11 \%$. Found: C $81.98 \%, \mathrm{H} 10.90 \%$.

Keywords: Columnar mesophases · Fluorescence · Gels · Organic semiconductors · Polyfused aromatic hydrocarbon (PAH)

\section{Author Information}

[a] J.-F. Hang, H. Lin, Prof. K.-Q. Zhao, Prof. P. Hu, Prof. B.-Q. Wang, College of Chemistry and Materials Science, Sichuan Normal University, Chengdu 610066, China, E-mail: kqzhao@sicnu.edu.cn

[b] Dr. H. Monobe, Nanomaterials Research Institute, National Institute of Advanced Industrial Science and Technology (AIST), Ikeda, Osaka, 5638577, Japan, E-mail: monobe-hirosato@aist.go.jp

[c] Dr. C. Zhu, Department Advanced Light Source, Lawrence Berkeley National Laboratory, 1 Cyclotron Rd., M/S 15R0217, Berkeley, CA 94720, USA

[d] Dr. B. Donnio, Institut de Physique et Chimie des Materiaux de Strasbourg (IPCMS), CNRS-Universite de Strasbourg (UMR 7504), Strasbourg, 67034, France, E-mail: bertrand.donnio@ipcms.unistra.fr

\section{Acknowledgement}

This research was financially supported by the National Natural Science Foundation of China (NSFC, Fund numbers: 51273133, 51773140, 51973143). KQZ and HM thank the support of NSFC-JSPS joint project (50811140156). BD thanks CNRS and University of Strasbourg for support.

Part of the joint "ECPM Strasbourg Institute Feature" Collection with EurJOC.

\section{Conflict of Interest}

The authors declare no conflict of interest.

\section{Supporting information}

Supporting information for this article is available on the WWW under https://doi.org/10.1002/ejoc.202100108 


\section{Biographical Information}

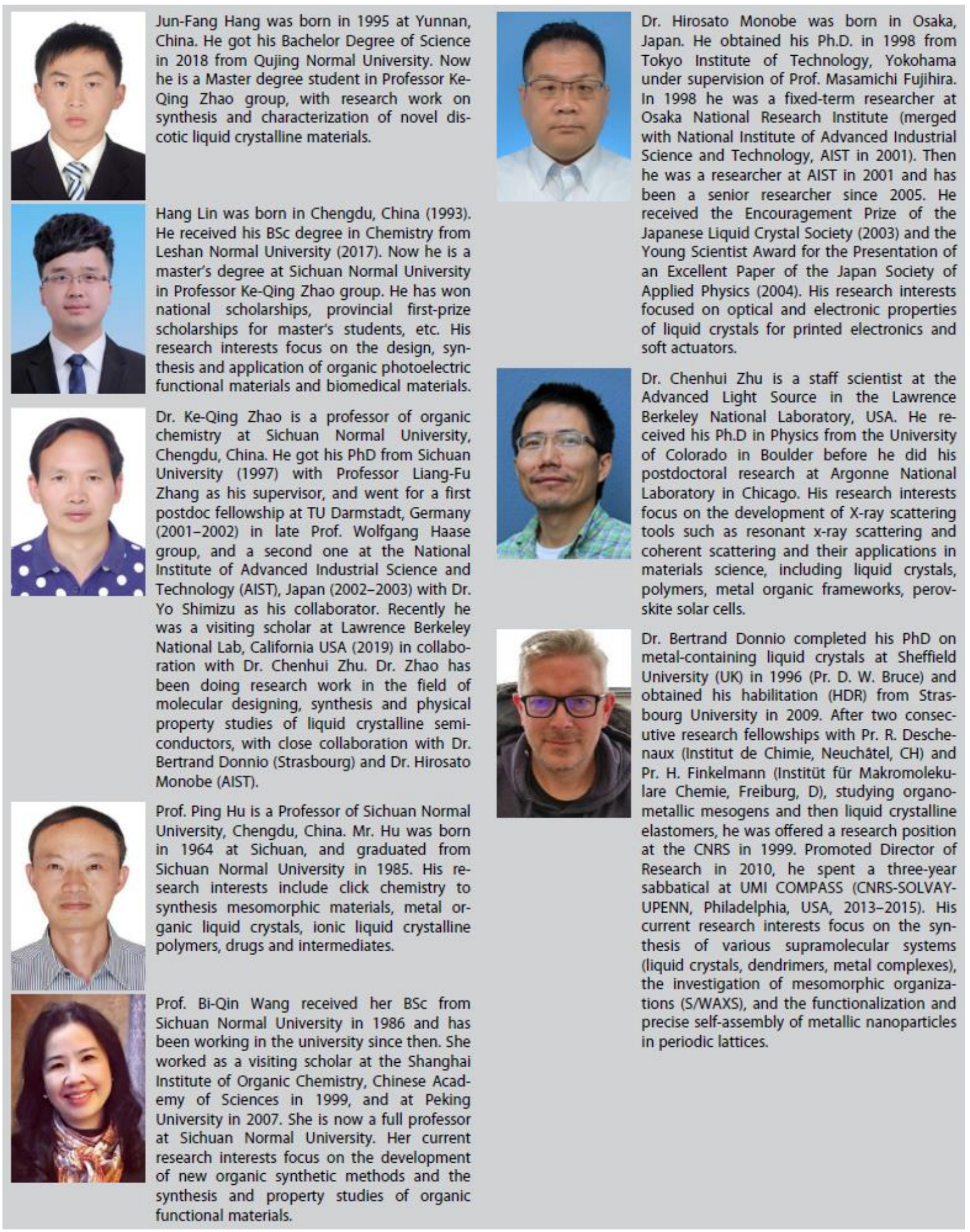

\section{References}

[1] A. C. Grimsdale, K. L. Chan, R. E. Martin, P. G. Jokisz, A. B. Holmes, Chem. Rev. 2009, 109, 897-1091.

[2] J. Li, A. C. Grimsdale, Chem. Soc. Rev. 2010, 39, 2399-2410.

[3] C. Wang, H. Dong, W. Hu, Y. Liu, D. Zhu, Chem. Rev. 2012, 112, 2208-2267. 
[4] a) S. Sergeyev, W. Pisula, Y. H. Geerts, Chem. Soc. Rev. 2007, 36, 1902-1929; b) T. Wohrle, I. Wurzbach, J. Kirres, A. Kostidou, N. Kapernaum, J. Litterscheidt, J. C. Haenle, P. Staffeld, A. Baro, F. Giesselmann, S. Laschat, Chem. Rev. 2016, 116, 1139-1241; c) B. R. Kaafarani, Chem. Mater. 2011, 23, 378-396.

[5] G. Hu, S. P. Kitney, M. R. Billa, S. M. Kelly, B. Lambert, W. Harrison, Liq. Cryst. 2021, 48, 63-74.

[6] a) G. Hu, S. P. Kitney, S. M. Kelly, W. Harrison, M. O. Neill, Liq. Cryst. 2017, 44, 1632-1645; b) G. Hu, M. R. Billa, S. P. Kitney, S. M. Kelly, Liq. Cryst. 2018, 45, 965-979.

[7] M. Manickam, M. Belloni, S. Kumar, S. K. Varshney, D. S. Shankar Rao, P. R. Ashton, J. A. Preece, N. Spencer, J. Mater. Chem. 2001, 11, 2790-2800.

[8] M. J. Sienkowska, H. Monobe, P. Kaszynski, Y. Shimizu, J. Mater. Chem. 2007, 17, 1392-1398.

[9] K. Q. Zhao, J. Q. Du, X. H. Long, M. Jing, B. Q. Wang, P. Hu, H. Monobe, B. Henrich, B. Donnio, Dyes Pigm. 2017, 143, 252-260.

[10] T. Yasuda, T. Shimizu, F. Liu, G. Ungar, T. Kato, J. Am. Chem. Soc. 2011, 133, 13437-13444.

[11] a) V. Iguarbe, J. Barbera, J. L. Serrano, Liq. Cryst. 2020, 47, 301-308; b) A. Concellon, R. Termine, A. Golemme, P. Romero, M. Marcos, J. L. Serrano, Org. Chem. Front. 2020, 7, 2008-2015.

[12] S. W. Kim, D. M. Lee, J. H. Kim, E. J. Choi, C. J. Yu, Liq. Cryst. 2019, 46, 1136-1144.

[13] a) S. Thiery, B. Heinrich, B. Donnio, C. Poriel, F. Camerel, J. Phys. Chem. C 2015, 119, 10564-10575; b) S. Thiery, B. Heinrich, B. Donnio, C. Poriel, F. Camerel, J. Mater. Chem. C 2014, 2, 4265-4275.

[14] W. W. H. Wong, T. B. Singh, D. Vak, W. Pisula, C. Yan, X. Feng, E. L. Williams, K. L. Chan, Q. Mao, D. J. Jones, C. Q. Ma, K. Mullen, P. Bauerle, A. B. Holmes, Adv. Funct. Mater. 2010, 20, 927-938.

[15] W. W. H. Wong, C. Q. Ma, W. Pisula, A. Mavrinskiy, X. Feng, H. Seyler, D. J. Jones, K. Mullen, P. Bauerle, A. B. Holmes, Chem. Eur. J. 2011, 17, 5549- 5560.

[16] Y. Yang, H. Wang, H. F. Wang, C. X. Liu, K. Q. Zhao, B. Q. Wang, P. Hu, H. Monobe, B. Heinrich, B. Donnio, Cryst. Growth Des. 2018, 18, 4296-4305.

[17] F. Lincker, A. J. Attias, F. Mathevet, B. Heinrich, B. Donnio, J. L. Fave, P. Rannou, R. Demadrille, Chem. Commun. 2012, 48, 3209-3211.

[18] F. Lincker, B. Heinrich, R. D. Bettignies, P. Rannou, J. Pecaut, B. Grevin, A. Pron, B. Donnio, R. Demadrille, J. Mater. Chem. 2011, 21, 5238-5247.

[19] a) B. Gomez-Lor, B. Alonso, A. Omenat, J. L. Serrano, Chem. Commun. 2006, 5012-5014; b) E. M. GarciaFrutos, U. K. Pandey, R. Termine, A. Omenat, J. Barbera, J. L. Serrano, A. Golemme, B. Gomez-Lor, Angew. Chem. 2011, 123, 7537-7540; Angew. Chem. Int. Ed. 2011, 50, 7399-7402; c) E. M. Garcia-Frutos, A. Omenat, J. Barbera, J. L. Serrano, B. Gomez-Lor, J. Mater. Chem. 2011, 21, 6831-6836.

[20] a) K. Q. Zhao, C. Chen, H. Monobe, P. Hu, B. Q. Wang, Y. Shimizu, Chem. Commun. 2011, 47, 6290-6292; b) L. L. Li, P. Hu, B. Q. Wang, W. H. Yu, Y. Shimizu, K. Q. Zhao, Liq. Cryst. 2010, 37, 499-506; c) H. L. Ni, H. Monobe, P. Hu, B. Q. Wang, Y. Shimizu, K. Q. Zhao, Liq. Cryst. 2013, 40, 411-420.

[21] a) S. Gomez-Esteban, A. Benito-Hernandez, R. Termine, G. Hennrich, J. T. Ljpez Navarrete, M. Carmen Ruiz Delgado, A. Golemme, B. Gomez-Lor, Chem. Eur. J. 2018, 24, 3576-3583; b) W. Zhang, W. H. Yu, C. Feng, S. K. Xiang, B. Q. Wang, K. Q. Zhao, H. L. Ni, P. Hu, Liq. Cryst. 2020, 47, 1100-1110; c) H. T. Xu, X. Xia, W. H. Yu, C. Feng, S. K. Xiang, B. Q. Wang, K. Q. Zhao, H. L. Ni, P. Hu, Liq. Cryst. 2021, 48, 111-120; d) P. Ruan, B. Xiao, H. L. Ni, P. Hu, B. Q. Wang, K. Q. Zhao, Q. D. Zeng, C. Wang, Liq. Cryst. 2014, 41, 1152-1161; e) K. Isoda, T. Yasuda, T. Kato, Chem. Asian J. 2009, 4, 1619-1625.

[22] N. Miyaura, A. Suzuki, Chem. Rev. 1995, 95, 2457-2483.

[23] a) M. Grzybowski, K. Skonieczny, H. Butenschon, D. T. Gryko, Angew. Chem. 2013, 125, 10084-10115; Angew. Chem. Int. Ed. 2013, 52, 9900-9930; b) M. Grzybowski, B. Sadowski, H. Butenschon, D. T. Gryko, Angew. Chem. 2020, 132, 3020-3050; Angew. Chem. Int. Ed. 2020, 59, 2998-3027; c) Y. Yang, J. Lan, J. You, Chem. Rev. 2017, 117, 8787-8863.

[24] T. Ma, H. F. Wang, K. Q. Zhao, B. Q. Wang, P. Hu, H. Monobe, B. Heinrich, B. Donnio, ChemPlusChem 2019, 84, 1439-1448.

[25] T. Ma, Y. J. Zhong, H. F. Wang, K. Q. Zhao, B. Q. Wang, P. Hu, H. Monobe, B. Donnio, Chem. Asian. J. DOI: 10.1002/asia.202100173.

[26] a) K. C. Zhao, J. Q. Du, H. F. Wang, K. Q. Zhao, P. Hu, B. Q. Wang, H. Monobe, B. Heinrich, B. Donnio, Chem. Asian J. 2019, 14, 462-470; b) C. X. Liu, H. Wang, J. Q. Du, K. Q. Zhao, P. Hu, B. Q. Wang, H. Monobe, B. Henrich, B. Donnio, J. Mater. Chem. C. 2018, 6, 4471-4478.

[27] K. Q. Zhao, Y. Gao, W. H. Yu, P. Hu, B. Q. Wang, B. Heinrich, B. Donnio, Eur. J. Org. Chem. 2016, 2802-2814.

[28] H. Huang, Q. Fu, B. Pan, S. Zhuang, L. Wang, J. Chen, D. Ma, C. Yang, Org. Lett. 2012, 14, 4786-4789.

[29] S. Kumar, Y. T. Tao, J. Org. Chem. 2015, 80, 5066-5076.

[30] F. Morale, R. W. Date, D. Guillon, D. W. Bruce, R. L. Finn, C. Wilson, A. J. Blake, M. Schroder, B. Donnio, Chem. Eur. J. 2003, 9, 2484-2501. 
[31] B. Donnio, B. Heinrich, H. Allouchi, J. Kain, S. Diele, D. Guillon, D. W. Bruce, J. Am. Chem. Soc. 2004, 126, 15258-15268.

[32] D. Myśliwiec, B. Donnio, P. J. Chmielewski, B. Heinrich, M. Stępień, J. Am. Chem. Soc. 2012, 134, 48224833.

[33] S. S. Babu, V. K. Praveen, A. Ajayaghosh, Chem. Rev. 2014, 114, 1973-2129.

[34] H. Monobe, Y. Shimizu, S. Okamoto, H. Enomoto, Mol. Cryst. Liq. Cryst. 2007, 476, 31-41.

[35] D. Adam, P. Schuhmacher, J. Simmerer, L. Haussling, K. Siemensmeyer, K. H. Etzbachi, H. Ringsdorf, D. Haarer, Nature 1994, 371, 141-143.

[36] R. J. Bushby, S. M. Kelly, M. O'Neill, in Liquid crystalline semiconductors. Materials, properties and applications. Springer Series in Materials Science, Springer, Dordrecht, 2013, vol. 169. 